\title{
Tomasz Rembalski
}

(Instytut Historii, Uniwersytet Gdański)

\section{Akta podatku gruntowego pruskich urzędów katastralnych jako źródło do badań struktury społeczno-majątkowej drobnej szlachty kaszubskiej w Prusach Zachodnich $(1861-1872)^{1}$}

Źródła pochodzenia fiskalnego dla niemal wszystkich epok dziejowych od lat cieszą się dużym zainteresowaniem wśród historyków, ze względu na ich ogromną wartość poznawczą ${ }^{2}$. Nietrudno zauważyć, iż w przypadku Pomorza Nadwiślańskiego z większym zainteresowaniem jak dotąd spotkał się jedynie kataster kontrybucyjny (zwany również fryderycjańskim) z lat 1772/1773 dla utworzonej po pierwszym rozbiorze Polski prowincji Prusy Zachodnie (Westpreußen) ${ }^{3}$. Stosunkowo licznie zachowane XIX-wieczne źródła podatkowe dla ziem polskich zaboru pruskiego (zwłaszcza Pomorza Nadwiślańskiego) nie zetknęły się jak dotąd, poza kilkoma wyjątkami, z większym zainteresowaniem ze strony badaczy. Z kolei dla ziem zaboru rosyjskiego i austriackiego powstało

1 Artykuł powstał w ramach międzynarodowego projektu Od szlachty do ziemiaństwa. Geneza i trwanie na obszarach niejednolitych etnicznie dawnej Rzeczpospolitej, finansowanego przez Narodowy Program Rozwoju Humanistyki przy Zarządzie Głównym Polskiego Towarzystwa Historycznego w Warszawie (PTH 50 NPRH 0156 FNiTP H 1280 2011).

2 Witold Kula, „Stan i potrzeby badań nad demografią historyczną dawnej Polski”, Roczniki Dziejów Społecznych i Gospodarczych 13 (1951): 23-106; Artur Eisenbach, „Struktura społeczna Królestwa w świetle schematów fiskalnych”, w Społeczeństwo Królestwa Polskiego. Studia o uwarstwieniu i ruchliwości społecznej, red. Witold Kula (Warszawa: Państwowe Wydawnictwo Naukowe, 1965), 24.

3 Ważniejsze publikacje na ten temat przedstawia: Dariusz Łukasiewicz, „Kataster fryderycjański dla Prus Zachodnich z 1772/73”, w Pomorze - Brandenburgia - Prusy (państwo i społeczeństwo). Księga pamiątkowa dedykowana Profesorowi Bogdanowi Wachowiakowi z okazji 70-lecia urodzin i 50-lecia pracy naukowej, red. Włodzimierz Stępiński, Zygmunt Szultka (Szczecin: AMP Paweł Majewski, 1999), 99-118. 
sporo prac, dla których podstawą do rozwiązywania problematyki struktury społeczno-majątkowej były źródła skarbowe ${ }^{4}$. Znajduje to odzwierciedlenie choćby w haśle „kataster”, zamieszczonym w Encyklopedii historii gospodarczej Polski. Oprócz wyjaśnienia pojęcia kataster, czyli że jest to „urzędowy spis nieruchomości z wykazem dochodów, sporządzany w celach podatkowych", hasło najdokładniej omawia kataster w zaborze austriackim. O ziemiach polskich pod zaborem pruskim napisano jedynie, iż zostały one objęte katastrem „stopniowo od schyłku XVIII w., [a] szczegółowe katastralne pomiary gruntów przeprowadzono dopiero od 1861, gdy sporządzono je w całym państwie pruskim”. Autorka hasła dodała jednocześnie, co jest tu istotne, że: „Akta katastralne stanowią cenne źródło do historii wsi, zwłaszcza struktury własności”s.

\section{II}

Urzędy katastralne $\mathrm{w}$ zaborze pruskim zostały powołane do życia Ustawą z 21 maja 1861 r. o odmiennym uregulowaniu podatku gruntowego ${ }^{6}$ (Gesetz vom 21. Mai 1861, betreffend die anderweite Regelung der Grundsteuer ${ }^{7}$ ). W myśl $\$ 1$ oddzielono od siebie podatek gruntowy od podatku budynkowego. Postanowienia ustawy, zgodnie $\mathrm{z} \$ 11$, działały dopiero od 1 stycznia $1865 \mathrm{r}^{8}$, gdyż do tego czasu nowo powołane urzędy musiały się należycie przygotować, zbierając dokumentację pomiarowo-ewidencyjną i szacunkową, która miała stanowić podstawę do rozpoczęcia administracji katastralnej. Początkowo urzędy zbierały dokumentację kartograficzną i inne materiały obcego pochodzenia, sporządzone wcześniej na potrzeby różnych zleceniodawców ${ }^{9}$ Zadaniem urzędów katastralnych było dokonywanie pomiarów gruntowych i obliczanie średniego faktycznego $\mathrm{z}$ nich dochodu (Reinertrag) w celu oszacowania podatku gruntowego i budynkowego ${ }^{10}$.

4 Tytułem przykładu: Eisenbach, „Struktura społeczna Królestwa”, 22-64; Tomasz J. Filozof, „Galicyjski kataster podatkowy jako źródło do badania struktury społecznej wsi”, Zeszyty Naukowe UJ. Prace Historyczne, 132 (2005): 109-123; Alicja Falniowska-Gradowska, Franciszek Leśniak, Struktura własności ziemskiej i użytkowania gruntów w Galicji w cyrkułach rzeszowskim, sanockim i tarnowskim w świetle katastru józefińskiego (1785-1887). (Toruń: Europejskie Centrum Edukacyjne, 2009). Dla prowadzonych przez autora niniejszego artykułu badań, duże znaczenie posiada praca: Krzysztof Ślusarek, Drobna szlachta w Galicji 1772-1848 (Kraków: Wydawnictwo „Księgarnia Akademicka”, 1994).

5 Barbara Grochulska, „Kataster”, w Encyklopedia historii gospodarczej Polski do 1945 roku, [t. I] (Warszawa: Państwowe Wydawnictwo „Wiedza Powszechna”, 1981), 304.

6 Grzegorz Roczek, „Akta urzędów katastralnych w zasobie archiwum inowrocławskiego”, Archeion 84 (1988): 71; Janusz Andrzejewski, Andrzej Krygier, Waldemar Sztukiewicz, „Kataster gruntowy w Wielkopolsce - historia i teraźniejszość”, Przegląd Geodezyjny 11 (1995): 17.

7 Gesetz-Sammlung für die Königlich Preußischen Staaten. 1806 bis 1880 incl. Chronologische Zusammenstellung [...], Bd. III. 1855 bis 1866 (Berlin: Carl Heymann's Verlag, 1881), 149-179.

8 Gesetz-Sammlung [...] 1855-1866, 149-150.

9 Roczek, „Akta urzędów katastralnych”, 71-72.

10 Max Bär, Die Behördenverfassung in Westpreußen seit der Ordenszeit (Danzig: Verlag und Druck von A.W. Kafemann G.m.b.H., 1912), 261. 
Pruskie urzędy katastralne posiadały dwie instancje, a nad całością pieczę sprawowały dwa ministerstwa: Rolnictwa i Skarbu. Zarząd katastralny znajdował się w kompetencjach rejencji (Regierung), w której już wcześniej posiadała Wydział Podatków, Domen i Lasów. W wydziałach tych ulokowano biura katastralne (Kataster Bureau), które zajmowały się szacunkiem wartości majątku podatników i wyznaczaniem wysokości należności podatku. Na ich czele stali inspektorzy katastralni, zwani także inspektorami rejencyjnymi, którzy kontrolowali bezpośrednio działalność urzędów katastralnych w powiatach, czyli niższej instancji. Te ostatnie w czasie swego funkcjonowania przeszły pewną ewolucję swej nazwy i funkcji. Początkowo w poszczególnych powiatach powołano urzędników, zwanych przejściowo Fortschreibungsbeamte, czyli „urzędników kontynuujących akta”. Od 1867 r. mianowano ich kontrolerami katastralnymi, przy czym każdy z nich musiał mieć kwalifikacje geometry i dłuższą praktykę w zawodzie. Nominację otrzymywali bezpośrednio z Ministerstwa Finansó $w^{11}$.

Powiatowe urzędy katastralne, $\mathrm{z}$ reguły znajdujące się w miastach będących siedzibami landratur, były przeważnie jednoosobowe. Niekiedy kontrolerzy katastralni, za wiedzą rejencji, mogli zatrudniać pomocników biurowych. Teren podległy poszczególnym urzędom katastralnym był podzielony na tzw. obręby (Gemarkung), w skład których wchodziła najczęściej jedna gmina lub samodzielny obszar dworski. Do głównych zadań urzędów katastralnych należało prowadzenie pomiarów gruntów i sporządzanie na ich podstawie map, klasyfikacja dochodów z ziemi i budynków oraz ewidencjonowanie zachodzących zmian. Co 15 lat odbywała się tzw. rewizja katastru, polegająca na uaktualnianiu przez geometrę zaistniałych zmian w nieruchomości, o których zobowiązani byli informować ich właściciele. Głównym celem tej czynności było sprostowanie przypisanego wcześniej podatku, z uwagi na zmiany w kulturze, dochodzie i wielkości areału. Rewizje takie prowadzono w latach 1880, 1895 i 1910. Każdy nowy piętnastoletni okres otwierało zaprowadzanie kolejnych tomów niektórych rodzajów ksiąg. Kataster budynkowy permanentnie uzupełniały urzędy katastralne na podstawie zgłoszeń przedstawicieli władz gminnych. Z kolei szacunki gruntów przeprowadzały specjalnie powołane do tego komisje powiatowe, które były nadzorowane przez rejencyjne Wydziały Podatków, Domen i Lasów. Obliczały one czysty zysk (Reinertrag) płynący z zagospodarowania ziemi, tworząc tzw. kataster zysku. Rewizje klasyfikacji dokonywano na podstawie wniesionej wcześniej reklamacji. Dwustopniowa organizacja władz katastralnych miała na celu permanentną kontrolę prowadzonych prac oraz właściwe zabezpieczenie dokumentacji pomiarowo-ewidencyjnej przed ewentualnym zniszczeniem ${ }^{12}$.

11 Bär, Die Behördenverfassung; Roczek, „Akta urzędów katastralnych..., 73-74; Czesław Biernat, Archiwum Państwowe w Gdańsku. Przewodnik po zasobie do 1945 roku (Warszawa-Łódź: Wydawnictwo Naukowe PWN, 1992), 221.

12 Roczek, „Akta urzędów katastralnych”, 74-76. 
Jak podaje Grzegorz Roczek, spośród wielkopolskich materiałów aktowych pochodzących ze szczebla rejencji (biura katastralnego) zachowały się głównie akta dotyczące postępowania urzędowego przy pomiarze, ewidencji szacunku gruntów oraz budynków, które zebrane były w oddzielne teczki dla każdego obrębu katastralnego. Noszą one tytuły: Verhandlungen über die Vermessung und Einschätzung Gebäudebeschreibungen, Grundsteuerverwaltung oraz Abschrift der Wiederholung zur Mutterrolle Gemarkung. Natomiast w powiatowych urzędach katastralnych powstawały: 1) matrykuły podatku gruntowego z wykazem artykułów i alfabetycznym spisem właścicieli (Mutterrolle und Muttersteuer, oraz Alphabetisches Namen der Grund und Gebäudeeigentümmer); 2) Księgi parcel (Flurbuch); 3) Księgi podatku budynkowego (Gebäudesteuerrolle) $)^{13}$.

\section{III}

Na objętym szerszymi badaniami etnicznym obszarze Kaszub w Prowincji Prusy Zachodnie - tj. ściśle powiatów: wejherowskiego, kartuskiego, kościerskiego, chojnickiego i człuchowskiego - na początku XIX w. funkcjonowało 51 wsi szlacheckich z podzieloną własnością. Znaczną część właścicieli gruntów i mieszkańców tych wsi stanowiła drobna szlachta kaszubska. Spośród tych miejscowości, dla 33 (ok. 65\%) zachowały się akta sprzed 1862 r. włączone do urzędów katastralnych, a wytworzone przez inne instytucje ${ }^{14}$. Dokumentacja aktowa wytworzona w trakcie organizowania tychże urzędów i przede wszystkim tycząca się oszacowania dochodowości gruntów i wymiaru podatku w latach 1862-1865, istnieje dla 32 dóbr drobnoszlacheckich (ok. 63\%). Przy czym dla powiatu kartuskiego istnieje kompletna dokumentacja, chojnickiego i człuchowskiego częściowa, zaś dla wejherowskiego, w skład którego wchodził wówczas również późniejszy (po 1887 r.) powiat pucki, nie ma żadnych tego typu materiałów. Szczegółowo ilustruje to zagadnienie tabela 1 .

Tabela 1. Stan zachowania akt urzędów katastralnych dla wsi drobnoszlacheckich na Kaszubach w Prusach Zachodnich

\begin{tabular}{|c|l|l|c|c|}
\hline 1.p. & $\begin{array}{l}\text { Nazwa dóbr szla- } \\
\text { checkich z podzie- } \\
\text { loną własnością } \\
\text { (wg danych z 1806 r.) }\end{array}$ & $\begin{array}{l}\text { Powiat według } \\
\text { podziału admini- } \\
\text { stracyjnego z lat } \\
\mathbf{1 8 1 8 - 1 8 8 7}\end{array}$ & $\begin{array}{l}\text { Akta regulacyjne } \\
\text { (separacyjne) } \\
\text { rejestry boni- } \\
\text { tacyjne (sprzed } \\
\mathbf{1 8 6 2} \text { r.) }\end{array}$ & $\begin{array}{l}\text { Akta katastral- } \\
\text { ne (pomiarowo- } \\
\text {-szacunkowe) } \\
\text { z lat 1862-1865 }\end{array}$ \\
\hline 1. & Dąbrówka & wejherowski & + & - \\
\hline 2. & Kętrzyno & wejherowski & - & - \\
\hline
\end{tabular}

\footnotetext{
13 Ibidem, 81-82.
}

14 W pierwszym rzędzie należy wymienić tu: recesy uwłaszczeniowe, separacyjne, rejestry bonitacyjne, następnie recesy dotyczące przeprowadzenia podziału wspólnot użytkowych zgodnie z ustawą z 1821 oraz wypisy z ksiąg hipoteczno-gruntowych. 


\begin{tabular}{|c|c|c|c|c|}
\hline l.p. & $\begin{array}{l}\text { Nazwa dóbr szla- } \\
\text { checkich z podzie- } \\
\text { loną własnością (wg } \\
\text { danych z } 1806 \text { r.) }\end{array}$ & $\begin{array}{l}\text { Powiat według } \\
\text { podziału admini- } \\
\text { stracyjnego z lat } \\
1818-1887\end{array}$ & $\begin{array}{l}\text { Akta regulacyjne } \\
\text { (separacyjne) } \\
\text { rejestry boni- } \\
\text { tacyjne (sprzed } \\
1862 \text { r.) } \\
\end{array}$ & $\begin{array}{l}\text { Akta katastral- } \\
\text { ne (pomiarowo- } \\
\text {-szacunkowe) } \\
\text { z lat 1862-1865 }\end{array}$ \\
\hline 3. & Łężyce & wejherowski & + & - \\
\hline 4. & Milwino & wejherowski & + & - \\
\hline 5. & Niepoczołowice & wejherowski & + & - \\
\hline 6. & Pobłocie & wejherowski & - & - \\
\hline 7. & Robakowo & wejherowski & + & - \\
\hline 8. & Strzebielino & wejherowski & + & - \\
\hline 9. & Tępcz & wejherowski & + & - \\
\hline 10. & Wiczlino & wejherowski & + & - \\
\hline 11. & Zelewo & wejherowski & + & - \\
\hline 12. & Borek i Borowy Las & kartuski & + & + \\
\hline 13. & Borucino & kartuski & + & + \\
\hline 14. & $\begin{array}{l}\text { Borzestowo } \\
\text { i Borzestowska Huta }\end{array}$ & kartuski & + & + \\
\hline 15. & Bukowa Góra & kartuski & + & + \\
\hline 16. & Częstkowo & kartuski & + & + \\
\hline 17. & Gostomie & kartuski & + & + \\
\hline 18. & $\begin{array}{l}\text { Grabowo } \\
\text { Parchowskie }\end{array}$ & kartuski & + & + \\
\hline 19. & Kożyczkowo & kartuski & + & + \\
\hline 20. & Mściszewice & kartuski & + & + \\
\hline 21. & Pałubice & kartuski & + & + \\
\hline 22. & Pierszczewo & kartuski & + & + \\
\hline 23. & Podjazy & kartuski & + & + \\
\hline 24. & Puzdrowo & kartuski & + & + \\
\hline 25. & Węsiory & kartuski & + & + \\
\hline 26. & Żukówko & kartuski & + & + \\
\hline 27. & Żuromino & kartuski & + & + \\
\hline 28. & Piechowice & kościerski & + & + \\
\hline 29. & Płachty & kościerski & + & + \\
\hline 30. & Sobącz & kościerski & + & + \\
\hline 31. & Stawiska & kościerski & - & + \\
\hline
\end{tabular}




\begin{tabular}{|c|c|c|c|c|}
\hline 32. & Wiec Nowy & kościerski & - & + \\
\hline 33. & Chełmy Małe & chojnicki & + & $t^{*}$ \\
\hline 34. & Czapiewice & chojnicki & - & - \\
\hline 35. & Czarnowo & chojnicki & - & $-^{*}$ \\
\hline 36. & Gliśno Małe & chojnicki & + & + \\
\hline 37. & Główczewice & chojnicki & - & + \\
\hline 38. & Orlik & chojnicki & - & $+^{*}$ \\
\hline 39. & Osowo & chojnicki & - & $+^{*}$ \\
\hline 40. & Wysoka Zaborska & chojnicki & + & $+^{*}$ \\
\hline 41. & Borzyszkowy & człuchowski & + & - \\
\hline 42. & Brzeźno Szlacheckie & człuchowski & - & - \\
\hline 43. & Czarnoszyce & człuchowski & - & - \\
\hline 44. & Gliśno Wielkie & człuchowski & - & + \\
\hline 45. & Gockowy & człuchowski & - & - \\
\hline 46. & Kiedrowice & człuchowski & - & - \\
\hline 47. & Lipnica & człuchowski & - & + \\
\hline 48. & Łąkie & człuchowski & + & + \\
\hline 49. & Ostrowite & człuchowski & - & + \\
\hline 50. & Prądzona & człuchowski & - & + \\
\hline 51. & Przechlewo & człuchowski & - & - \\
\hline
\end{tabular}

- brak akt

+ akta istnieją

* Zachowany spis podatku gruntowego (Grundsteuerheberolle) z 1865 r., z wykazem jego wymiaru i nazwisk wszystkich właścicieli-podatników.

Źródło: Opracowanie na podstawie objętej kwerendą zachowanej dokumentacji lub inwentarzy archiwalnych akt urzędów katastralnych.

W niniejszym szkicu nie zostanie podjęta wnikliwa analiza systemów podatkowych obowiązujących w tzw. prowincjach wschodnich hohenzollernowskich Prus, ani pełna charakterystyka zachowanych źródeł pochodzenia fiskalnego. Jego celem jest zwrócenie uwagi na konkretną przydatność badawczą, czyli strukturę społeczno-majątkową drobnej szlachty kaszubskiej. Podstawę stanowią tu akta dotyczące podatku gruntowego, tworzone przez urzędy katastralne w latach 1861-1872, a więc w fazie ich organizowania i początkowego funkcjonowania, co zaowocowało zachowaniem najciekawszego poznawczo materiału ${ }^{15}$.

15 W przypadku akt dotyczących podatku gruntowego przyjęto, iż kwerenda w materiale wchodzącym w skład zespołów archiwalnych o nazwie Urząd Katastralny, nie będzie wykraczać 
Analiza obejmuje trzy powiaty Prowincji Prusy Zachodnie, mianowicie: człuchowski, chojnicki i kartuski, co umotywowane jest w miarę dobrym ich rozpoznaniem ${ }^{16}$.

Pominięte zostały bardzo interesujące akta katastralne dotyczące podatku budynkowego (zwanego również „domowym” ${ }^{17}$ ) z tego względu, iż w polskich archiwach zachowały się one wyłącznie dla „zachodniopruskich” wsi drobnoszlacheckich z powiatu człuchowskiego ${ }^{18}$. Warto jednak podkreślić, iż mają one dużą wartość historyczną. Dla obrębów tego powiatu zachowały się dwa wykazy oszacowania (Veranlagungsnachweisung) podatku budynkowego $\mathrm{z}$ grudnia $1862 \mathrm{r}$. W wykazach tych zwracają uwagę cenne informacje o typach, konstrukcji i stanie budynków w poszczególnych zagrodach. Ponadto przy każdym właścicielu nieruchomości podano wielkość posiadanego areału ziemi (sumarycznie), więc jest to niewątpliwie cenny materiał do badań struktury majątkowej we wsiach powiatu człuchowskiego. Warto wspomnieć, iż te jednostki archiwalne na oryginalnych okładkach mają nalepki z napisem: „Kreis Schlochau. Kataster Amt Konitz”, co mogłoby świadczyć o tym, iż w początkowym okresie powiat człuchowski podlegał urzędowi katastralnemu w Chojnicach ${ }^{19}$.

poza 1872 r. Autor artykułu przygotowuje monografię pt. Własność drobnoszlachecka na Kaszubach w Prowincji Prusy Zachodnie w latach 1772-1872. Rozmieszczenie i struktura. Omawiane akta urzędów katastralnych mają stanowić podstawowy materiał do opracowania najmłodszego dla pracy przekroju struktury własnościowej w kaszubskich wsiach drobnoszlacheckich.

16 Archiwum Państwowe w Bydgoszczy (APB), Urząd Katastralny w Chojnicach (UKCh), nr 2263, do którego po 1920 r. zostały włączone akta podatku gruntowego z części powiatu człuchowskiego (Gochy), przyznanego mocą traktatu wersalskiego Polsce oraz Archiwum Państwowe w Gdańsku (APG), Urząd Katastralny w Kartuzach (UKK), nr 114. Z podobnych przyczyn, jak w przypadku kaszubskich Gochów, przy czym w odwrotnym kierunku, w 1920 r. oderwano od powiatu kartuskiego szlachecką wieś Żukówko i przyłączono ją do powiatu bytowskiego, znajdującego się do 1945 r. w granicach Niemiec. Z tego powodu akta katastralne dla tej wsi, mimo iż noszą cechy Urzędu Katastralnego w Kartuzach (Katasteramt Karthaus), znajdują się obecnie w Archiwum Państwowym w Koszalinie Oddział w Słupsku (APS), w zespole Urząd Katastralny w Bytowie, nr 80 , sygn. 809-813.

Przedłużający się remont budynku APG nie pozwolił na przebadanie zachowanych akt urzędów katastralnych w Kościerzynie (nr 111) - liczącego 1000 j.a. i w Wejherowie (nr 118) - obejmującego jedynie 427 j.a. [Biernat, Archiwum Państwowe w Gdańsku, 222, 224]. Jednakowoż pobieżna analiza inwentarzy archiwalnych nie daje nadziei na dokonanie spektakularnych odkryć w tychże zespołach. W aktach kościerskich dominują akta z drugiej połowy XIX i początku XX w. Dokumentacja dotycząca oszacowania podatku gruntowego w latach 1862-1864 zachowała się dla: Płacht (nr 648), Starego Wiecu (nr 675), Piechowic (nr 709), Stawisk (nr 761) oraz Sobącza (nr 772). Brakuje recesów separacyjnych i regulacyjnych dla Stawisk i Nowego Wieca. W przypadku powiatu wejherowskiego nie zachowały się akta z lat 1862-1865.

17 Przykładowo zob. Bolesław Koskowski, Polityka gminna (Warszawa: Nakład Gebethnera i Wolffa; Kraków: G. Gebethner i Spółka, 1907), 127.

18 APS, Urząd Katastralny w Człuchowie (UKCz), nr 747.

19 APS, UKCz, nr 747, sygn. 813, 814. 


\section{IV}

Po przedstawieniu genezy urzędów katastralnych w państwie pruskim, a także oceny stopnia zachowania akt dla powiatów kaszubskich Prus Zachodnich, należy przejść do bardziej szczegółowego omówienia ich zawartości.

W obrębie zespołu Urząd Katastralny w Kartuzach w omawianym okresie, dla niemal wszystkich wsi szlacheckich zachowały się podobne $\mathrm{w}$ treści poszyty. Największe różnice dotyczą akt powstałych przed 1862 r., które posłużyły do ustalenia faktycznego stanu majątkowego w poszczególnych miejscowościach. Przeważnie wynika to $\mathrm{z}$ różnego, niekiedy bardzo skomplikowanego, procesu przeprowadzania reform po wojnach napoleońskich, co niejednokrotnie prowadziło do przeciągających się procesów administracyjno-sądowych. Do najtrudniejszych należały sprawy związane $\mathrm{z}$ separacjami ${ }^{20}$ i przeprowadzaniem podzialów wspólnot użytkowych.

Ogółem w zespole Urząd Katastralny w Kartuzach znajduje się 1569 jednostek archiwalnych ${ }^{21}$, z których zdołano wydzielić około 60 poszytów dla 20 wsi i osiedli drobnoszlacheckich: Borek i Borowy Las, Borzestowo, Borzestowska Huta, Borucino, Bukowa Góra, Gostomie, Podjazy, Klukowa Huta, Kożyczkowo, Grabowo Parchowskie, Mściszewice, Pałubice, Pierszczewo, Puzdrowo, Żuromin, Tokary, Tuchlin, Węsiory oraz Częstkowo. Przy czym należy pamiętać, iż z części tych wsi w pierwszej połowie XIX w. drobna szlachta kaszubska została wyrugowana.

Dla przykładu, w poszycie dotyczącym (według tytułu) recesu podziału wspólnot gminnych we wsiach Borek i Borowy Las, sporządzonych przez landraturę kartuską, znajdują się m.in. odpisy wykazów posiadłości interesantów biorących udział w podziale wspólnot gminnych $\mathrm{z}$ lat 1841-1845, różne recesy zatwierdzone w latach 1849-1867 oraz bardzo cenny dla badań stanu posiadania ekstrakt z rejestru bonitacyjnego z $1839 \mathrm{r}$. Na końcu poszytu nieoczekiwanie znalazł się wykaz podatku gruntowego dla poszczególnych właścicieli nieruchomości, według matrykuły podatkowej z 1865, w odpisie z 1868 r. (aneks nr 1) ${ }^{22}$.

Wyjątkowość owego wykazu polega na tym, iż dotąd nie udało się odnaleźć podobnego materiału dla innych miejscowości w omawianych zespołach archiwalnych. Wynika z niego, iż w Borku oraz administracyjnie z nim złączonym Borowym Lesie było opodatkowanych ponad 4100 morgów (M). Ziemi szlacheckiej było łącznie 61,7\% (ponad $2533 \mathrm{M}$ ). W tym majątek rycerski (Rittergut), należący do Friedricha Haacka (zapewne nieszlachcica pochodzenia niemieckie-

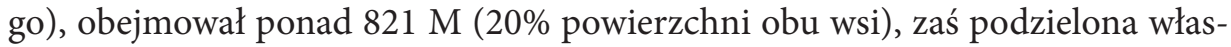
ność rycerska należała do 8 posiadaczy (Rittergutsanteilbesitzer), której łącznie

20 Przykładowo pisze o tym Józef Borzyszkowski, „W państwie prusko-niemieckim”, w Historia Brus i okolicy, red. Borzyszkowski (Gdańsk-Brusy: Urząd Miejski w Brusach, Instytut Kaszubski, 2006), 212-218.

21 Biernat, Archiwum Państwowe w Gdańsku, 222.

22 APG, UKK, nr 114, sygn. 102, Acta des Königlichen Landrats-Amt Carthaus betreffend der Gemeinheitstheilungs-Rezess von Borrek und Borrowilass, bez paginacji (dalej cyt. b.p.). 
było ponad $1712 \mathrm{M}(41,7 \%)$. Powierzchnie poszczególnych majątków drobnoszlacheckich były bardzo zróżnicowane, gdyż kształtowały się od prawie $40 \mathrm{M}$ (Ignacy Malek) do ponad 369 M (Juliusz Piechowski). Mimo tej rozpiętości, średnia była i tak wysoka, gdyż wynosiła ponad $213 \mathrm{M}$, czyli w przeliczeniu około 50 ha. Ziemi chłopskiej (Rentenbauer $=$ gburstw rentowych) było $w$ tych wsiach $26,6 \%$ (1091 M), pozostałą część (11,6\%) obejmowało jezioro, stanowiące wspólną własność posiadaczy ziemi. Interesujące, iż właścicielami większości chłopskiej ziemi były osoby o kaszubskich nazwiskach szlacheckich. Niektórzy z nich, o których wiadomo, iż przede wszystkim posiadali dział szlachecki w Borku, najpewniej wydzierżawiali te gospodarstwa innym użytkownikom. Przy uwzględnieniu tego aspektu okazuje się, iż w rękach drobnej szlachty znajdowało się 2578,5 M chłopskiej i rycerskiej ziemi, co stanowiło 62,9\% ogółu.

Drugi poszyt dla tych wsi nosi tytuł Verhandlungen über die Vermessung, Einschätzung etc., czyli dotyczy pertraktacji w sprawie pomiarów i oszacowania podatku gruntowego. Zawiera on m.in. odrys planu wsi w skali 1:500023, obliczenia powierzchni (Flächeninhaltsberechnung) oraz masy (Massenberechnung), lecz dwa ostatnie dokumenty nie posiadają wyszczególnionych nazwisk właścicieli, a jedynie numery działek, co w znaczny sposób utrudnia ich wykorzystanie. Nazwiska właścicieli zawiera z kolei wyciąg z planu separacyjnego z 1842 r., wraz z wykazem stanu posiadania z 1841 oraz wyciąg z rejestru bonitacyjnego z 1859 r. - wszystko w formie jednej tabeli, gdzie przy nazwiskach właścicieli podano powierzchnię posiadanych gruntów. W dalszej kolejności znajduje się rejestr oszacowania (Einschätzungregister) oraz zbiorczy wykaz użytków rolnych według ich klasyfikacji (Klassenzusammenstellung). Oba formularze nie mają rubryki z nazwiskami. Wszystkie wymienione dokumenty sporządzono 28 września 1863 r. Następnie znajduje się wydzielona grupa akt zatytułowanych Untervertheilung der Grundsteuersummen im Gemeindebezirk und Selbstständigen Gutsbezirk Borrek und Borrowilass, a więc "podpodziały” sum podatku gruntowego $\mathrm{w}$ gminie i samodzielnym obwodzie dworskim Borek i Borowy Las. Na pierwszym miejscu zamieszczono imienny wykaz wszystkich posiadaczy gruntowych (Namensverzeichniß sämmtlicher Grundbesitzer), względem którego zastrzeżono, iż mieli się w nim znaleźć wszyscy właściciele gruntów oraz budynków znajdujących się w obrębie gminy lub obwodu dworskiego, niezależnie od tego, czy zamieszkiwali tam, czy też poza ich granicami. Wszystkie nazwiska właścicieli należało podać w formie alfabetycznej. Każdy wpis musiał zawierać informacje o nazwisku, stanie, numerze domu i miejscu zamieszkania właściciela. W dalszej kolejności trzeba było podać sygnaturę posiadłości z księgi hipotecznej oraz „w sposób wiarygodny określić” kwalifikację posiadłości, a więc, czy

23 Plan ten (lub plany), podobnie jak w przypadku większości planów innych obrębów powiatu kartuskiego, są wszyte w poszyt w taki sposób, że ich rozłożenie, a tym samym zbadanie, jest niemożliwe. 
był to przykładowo majątek gburski (Bauerngut), zagrodniczy (Kossäthengut), czy jakakolwiek parcela chałupnicza (Gärtnerstelle, Häuslerstelle etc.). W ostatnim czwartym punkcie znalazło się polecenie, aby osoba sporządzająca wykaz podpisała go, poprzedzając następującą formułą: "daß die darin enthaltenen Angaben nach bestem Wissen und Gewissen gemacht sein” (czyli, „że zawarte $\mathrm{w}$ nim informacje są wykonane z moją najlepszą wiedzą i przekonaniem"). I rzeczywiście, pod sporządzonym 21 września 1864 r. wykazem, za całe szlacheckie dominium podpisał się w ten sposób Friedrich Haack -jedyny posiadacz „pełnego" majątku rycerskiego w Borku. Jednakże w formularzu tym nie przewidziano miejsca na podanie powierzchni posiadanych gruntów. W szczegółach przedstawia to aneks $\mathrm{nr} 2$, z którego analizy wynika, iż w obu miejscowościach był jeden majątek rycerski (Rittergut), 8 cząstkowych dóbr rycerskich (Rittergutsantheil) oraz 20 gburskich dóbr rentowych (Rentenbauergut).

Następnie w tym samym poszycie umieszczono wykaz - również sporządzony 21 września 1864 r. - posiadanych parcel przez poszczególnych właścicieli (Verzeichniß der Besitzstücke im Gemeinde und selbstständige Gutsbezirk Borrek und Borrowilas ${ }^{24}$ ), gdzie znalazły się informacje o numerach separacyjnych gospodarstw oraz zestawienie numerów parcel z planu obrębu (Gemarkungskarte), ale bez podania ich powierzchni. W odróżnieniu od poprzedniego wykazu różnił się tym, iż prócz właścicieli gruntowych, odnotowywał także parcele wspólne (np. jeziora) lub gminne (np. szkoła).

Po obu imiennych wykazach, do poszytu wpisano jeszcze wyniki dodatkowych pomiarów (Nachtrag-Vermessung), wyjaśnienie różnic między rejestrem oszacowań itp. a księgą parcel (Erläuterung der Unterscheide zwischen dem Einschätzungregister u.s.w. und dem Flurbuch) oraz zestawienie klas [bonitacyjnych] i obliczenie czystego dochodu do księgi parcel (Zusammenstellung der Klassen und Berechnung des Reinertrages zum Flurbuch $)^{25}$. Nie posiadają one jednak zestawienia nazwisk podatników.

Trzeci poszyt dla Borka i Borowego Lasu z lat 1866-1901 nie ma oryginalnej karty tytułowej, lecz na podstawie analizy zawartości i porównania $\mathrm{z}$ aktami innych obrębów katastralnych, można przyjąć, iż są to akta dotyczące negocjacji w sprawie kontynuacji w księgach podatku gruntowego i planach (Acta betreffen die Verhandlungen über die Fortschreibung der Grundsteuerbücher und Karten) ${ }^{26}$. Tak jak podano w przytoczonej literaturze, ten typ akt w zasadzie nie zawiera pełnych wykazów właścicieli gruntów w danej wsi, a jedynie odnotowuje te własności, w których zaszły jakiekolwiek zmiany. Tym samym można, i należy, sięgać do nich

24 W późniejszym czasie skreślono ołówkiem część tytułu „und selbstständige Gutsbezirk”, podważając szlachecki status tej miejscowości.

25 APG, UKK, nr 114, sygn. 103, Grundsteuer-Veranlagung. [...] Gemarkung Borreck, No 14. Verhandlungen über die Vermessung, Einschätzung etc., b.p.

26 APG, UKK, nr 114, sygn. 104; APG, UKK, nr 114, sygn. 127, Acta betreffen die Verhandlungen über die Fortschreibung der Grundsteuerbücher und Karten des Gemeindebezirks Borruczyn. 
jedynie w przypadku badania dziejów poszczególnych gospodarstw (rodzin). Dla określania struktury własnościowej wsi akta te nie mają większej wartości.

Zespół archiwalny Urzędu Katastralnego w Chojnicach zachował 821 jednostek archiwalnych ${ }^{27}$, lecz w odróżnieniu od kartuskiego, jego akta są w znacznym stopniu zdekompletowane, zwłaszcza w odniesieniu do wsi drobnoszlacheckich. Akta oszacowania podatku gruntowego (1862-1864) zachowały się dla 6 z 8 wsi drobnoszlacheckich: Małego Gliśna, Główczewic, Małych Chełmów, Orlika, Osowa i Wysokiej Zaborskiej ${ }^{28}$.

W przypadku Główczewic (aneks nr 3), mimo iż nie wymagał tego formularz, przy każdym właścicielu wpisano areał posiadanych gruntów. Charakterystyczne, że ziemię tylko jednego posiadacza zakwalifikowano jako majątek rycerski. Był nim Józef Bruski, właściciel 1200 M, i co ciekawe nieszlachcic, lecz potomek lemanów z nieodległych Brus. Pozostałych 10 posiadaczy (Besitzer), z których przynajmniej 6 mogło wykazać szlacheckich przodków ${ }^{29}$, nie zostało zakwalifikowanych przez urzędników do cząstkowych posiadaczy dóbr rycerskich, lecz właścicieli majątków gburskich (Bauergut). W tej grupie przeciętny nadział ziemi wynosił nieco ponad $173 \mathrm{M}$, przy czym najmniej ziemi posiadał Stanisław Koliński (52 M), najwięcej Jan Kiedrowski (442 M), zaś Jan Rekowski i Franciszek Langowski wspólnie uprawiali 292 M. Ponadto zamieszkiwało w niej 9 chałupników (Käthner) posiadających gospodarstwa chałupnicze (Käthnergut, Häuslerstelle) oraz jeden zagrodnik (Kosat) władający gospodarstwem zagrodniczym o powierzchni $27 \mathrm{M}$. Gospodarstwa chałupnicze obejmowały od $1 / 4$ do 53 M. Uderzający w tym wykazie jest fakt, iż powierzchnia posiadanej ziemi nie zawsze przekładała się na jej kwalifikację. Granica między gburstwem a własnością chałupniczą była bardzo nieostra.

W chojnickim urzędzie katastralnym recesy separacyjne istnieją tylko dla trzech wsi: Małego Gliśna, Wysokiej Zaborskiej oraz Małych Chełmów ${ }^{30}$. Ponadto znalazły się tam wykazy zmian zatytułowane Supplement-Akten. Na pierwszych kartach tych akt zamieszczono wypisy ze spisu podatku gruntowego (Grundsteuerheberolle) i budynkowego (Gebäudeheberolle) z wykazem wszystkich właścicieli opłacających podatek (z ich wymiarem) w poszczególnych wsiach, to jest: Małych Chełmów, Orlika, Wysokiej Zaborskiej, Osowa i Czarnowa ${ }^{31}$.

Wykaz podatkowy dla Czarnowa (aneks nr 4) nie ma wyszczególnienia ilości opodatkowanej ziemi, lecz jedynie wymiar podatku. Strukturę majątkową można w tym wypadku określić wyłącznie na podstawie wysokości podatku. We wsi w tym czasie było 14 posiadaczy majątków cząstkowych (Gutsantheilsbesitzer), z których

27 Naczelna Dyrekcja Archiwów Państwowych (NDAP). Bazy danych [online], dostęp: [15.01.2015] http://baza.archiwa.gov.pl/sezam/sezam.php?l=pl\&mode=show\&zespoly_id=8081.

28 APB, UKCh, nr 2263, sygn. 334, 337, 423, 474, 477-478, 574.

29 Nie obdarzono ich szlachecką partykułą „,von”.

30 APB, UKCh, nr 2263, sygn. 829, 839, 842.

31 APB, UKCh, nr 2263, sygn. 41, 173, 228, 270, 318. 
jedynie u połowy przed nazwiskiem widniał szlachecki predykat „von”, co oznaczało, iż druga połowa wywodziła się z rodzin nieszlacheckiego pochodzenia. Przy czym to właśnie owi posiadacze cząstkowych dóbr rycerskich nieszlacheckiego pochodzenia (Paweł Karnowski i Józef Bruski) płacili najwyższe podatki, co oznacza, iż posiadali najwięcej ziemi w Czarnowie. We wsi znajdowało się także 7 gospodarstw chałupniczych (Käthner), z których dwa posiadały osoby o szlacheckich nazwiskach (Józef Lipiński i Szymon Czarnowski).

Do katastru chojnickiego zostały również wciągnięte akta wsi wyłączonych po $1920 \mathrm{r}$. z powiatu człuchowskiego ${ }^{32}$. Akta oszacowania wymiaru podatku $\mathrm{z}$ lat 1863-1865 posiada zaledwie 5 z 11 wsi: Wielkie Gliśno z jeziorem, Lipnica, Łąkie, Ostrowite i Prądzona ${ }^{33}$.

Przydatność tych akt do badań przedstawiono na przykładzie „Wyciągu z ksiąg hipotecznych dla wszystkich posiadłości w gminie Prądzona" z 1864 r. (aneks nr 5). Mimo iż zadbano o to, aby w wyciągu znalazły się dane o numerze hipotecznym własności, dacie dokumentu jej nabycia, imieniu i nazwisku właściciela, kwalifikacji nieruchomości, zwraca uwagę fakt, iż w rubryce "powierzchnia” (Flächeninhalt) znajdują się znaczące luki. Zdaje się, iż nie wynikają one z winy urzędnika katastralnego, a raczej z braku dokładności ksiąg hipotecznych, co można zaobserwować nie tylko w stosunku do tej wsi. Najistotniejsze w tym wypadku informacje niesie za sobą rubryka dotycząca kwalifikacji posiadłości. Wynika z niej, iż w Prądzonie w 1864 r. istniało 11 działów dóbr rycerskich (Ritterguts-Antheil), a spośród ich właścicieli jedynie trzech nie miało pochodzenia szlacheckiego. Zauważalne było jednocześnie znaczne rozdrobnienie własności szlacheckiej dokonane w latach 1841-1862 na dziale rycerskim oznaczonym literą „G”, z którego wydzielono 12 nowych własności. Występowało także 7 gburstw (Bauerhof) o różnej powierzchni ziemi (od 1/2 do 2 włók) oraz 9 działek chałupniczych (Käthnergrundstück), skąd ostrożnie wnioskować można, iż nie było tu ścisłych kryteriów podziału na kategorie na podstawie areału ziemi, lecz zaszłości historycznych. Wśród właścicieli dwóch ostatnich kategorii występowało 7 osób o szlacheckich nazwiskach. Z pewnością niebagatelną rolę odgrywali we wsi posiadacze młyna i karczmy, którymi najpewniej byli Niemcy. Niejasna natomiast była pozycja gruntów oznaczonych jako „Grundplan” i „Acker”.

Wracając do stanu zachowania akt dla powiatu człuchowskiego, należy wspomnieć, iż jedynie dla 2 wsi zachowały się recesy separacyjne, tj. Borzyszkowy i Łąkiego ${ }^{34}$. W przypadku wsi Borzyszkowy, która pomierzona była w dwóch sekcjach, w aktach katastralnych zachował się pełen odpis tylko sekcji II. W aneksie 6 zamieszczono dla przykładu „Ekstrakt $\mathrm{z}$ rejestru pomiarów bonitacyjnych

32 Na kartach tytułowych przekreślono napisy „Kreis Schlochau” i nadpisane „Powiat Chojnice”.

33 APB, UKCh, nr 2263, sygn. 335-336, 404-405, 417-418, 483-484, 503.

34 APB, UKCh, nr 2263, sygn. 823, 828. 
pól wsi Borzyszkowy” z 1856 r., który unaocznia szczegółowość tego typu dokumentacji. Ponadto w zespole przechowywane są również wykazy zmian zatytułowane "Supplement-Akten” lub „Grundsteuer-Fortschreibung-Akten” dla 8 wsi: Brzeźno Szlacheckie, Gliśno Wielkie, Kiedrowice, Lipnica, Łąkie, Ostrowite, Prądzona i Smołdziny-Lipnica (wspólnie dwie sąsiadujące miejscowości). Nie ma jednak dla nich pełnych spisów podatkowych, tak jak miały to obręby ze „starego" powiatu chojnickiego, gdzie przy każdym z właścicieli podano dokładny wymiar podatku ${ }^{35}$.

Pobieżne omówienie dla różnych obrębów katastralnych wybranych przykładowo typów dokumentacji, tworzonych w ramach funkcjonujących urzędów, ilustruje duże możliwości badawcze. Pokazuje mocne i słabe strony poszczególnych wykazów, wyciągów, rejestrów itp., ale i również daje nadzieję, mimo pewnych braków, na uzyskanie wiernego obrazu sytuacji społeczno-majątkowej w poszczególnych wsiach w wyniku ich łącznego wykorzystania.

\section{$\mathrm{V}$}

Braki czy luki w odpisach akt separacyjnych lub innego typu dokumentacji związanej z pruskimi reformami $\mathrm{w}$ rolnictwie, a znajdujące się $\mathrm{w}$ zespołach archiwalnych urzędów katastralnych, w łatwy sposób można zastąpić ich pierwopisami. W większej części zachowały się one w zespole Komisja Generalna $\mathrm{w}$ Bydgoszczy $^{36}$. Z reguły są obszerniejsze i bardziej kompletne, co sprawdzono na przykładzie obrębu Borzyszkowy ${ }^{37}$. Większość z nich datowana jest na lata 40. i 50. XIX w.

Dużo większym wyzwaniem badawczym jest zrekonstruowanie stanu majątkowego we wsiach szlacheckich w latach 60. XIX w. Oczywiście można posiłkować się zachowanymi księgami hipoteczno-gruntowymi, co robili już pruscy urzędnicy katastralni. Przy czym nie zawsze w tego typu aktach znajdują się informacje o powierzchni gruntów dla poszczególnych posiadłości, co najlepiej zilustrował aneks nr 2, sporządzony dla Prądzony. Dla tego powiatu duże znaczenie będzie miało przebadanie akt dotyczących podatku budynkowego, które zachowały się w miarę kompletnie ${ }^{38}$. To jedyne tego typu akta zachowane dla kaszubskich powiatów Prus Zachodnich. Niestety nie udało się odszukać akt rewizji katastru, który miał następować co 15 lat.

35 Ibidem, sygn. 25, 69, 120, 139, 157, 214, 219, 313.

36 APB, Pruska Komisja Generalna dla Prowincji Zachodniopruskiej i Poznańskiej w Bydgoszczy (KG Bydgoszcz), nr 52. Zespół liczy 113255 j.a. z lat 1812-1920, zob. NDAP. Bazy danych [online].Dostęp:[19.01.2015] http://baza.archiwa.gov.pl/sezam/sezam.php?l=pl\&mode=show\& zespoly_id=5412.

37 Zachował się brakujący w aktach urzędu katastralnego rejestr bonitacyjno-pomiarowy sekcja I. APB, KG Bydgoszcz, nr 52/9, sygn. 33.

38 Zob. przyp. 17. 
Natomiast w przypadku powiatów chojnickiego (częściowo) i całego wejherowskiego należałoby odwołać się do innego typu akt, przykładowo dotyczących abluicji ciężarów na rzecz instytucji kościelnych, dokonanych na przełomie lat 70. i 80. XIX w. Tego typu akta zachowały się w wspomnianej już Komisji Generalnej oraz niekiedy $\mathrm{w}$ archiwach kościelnych (czasami jeszcze parafialnych).

Nie ma wątpliwości, iż wstępna analiza akt urzędów katastralnych dokonana dla wsi drobnoszlacheckich, mimo znaczących braków w zasobach archiwalnych, potwierdza ich dużą przydatność badawczą. Analogiczne badania można prowadzić również względem gmin wiejskich, czyli dawnej własności królewskiej i kościelnej. Zawarte w nich informacje o rodzajach i powierzchni gruntów, wymiarze podatku (niestety w bardzo małym stopniu zachowanych dla powiatów kaszubskich w Prusach Zachodnich), czy wreszcie statusie społecznym poszczególnych właścicieli, pozwalają mieć nadzieję na uzyskanie interesujących danych na temat struktury społeczno-własnościowej XIX-wiecznej wsi pomorskiej. 


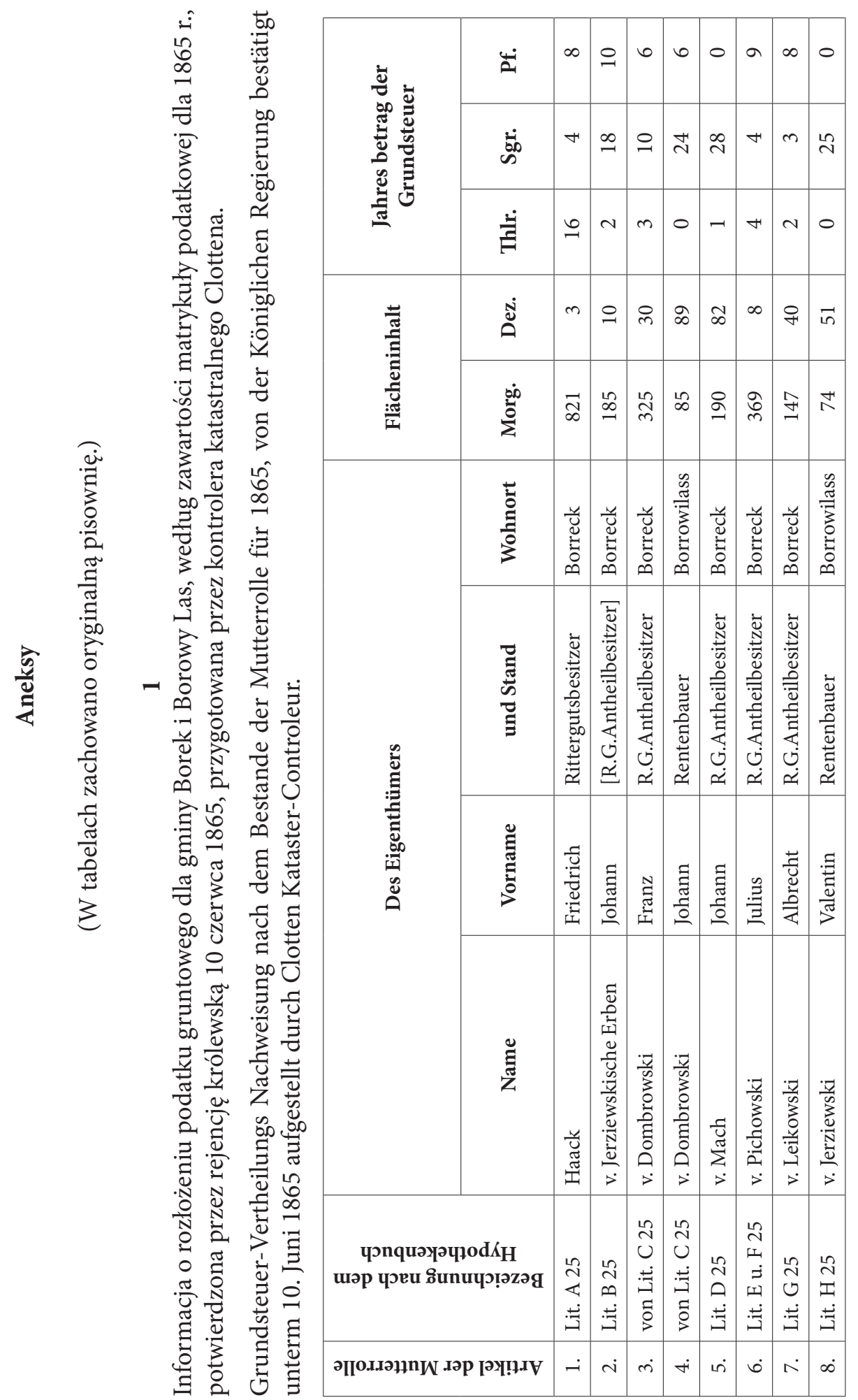




\begin{tabular}{|c|c|c|c|c|c|c|c|c|c|c|c|c|c|c|c|c|c|c|c|c|c|}
\hline$N$ & $m$ & $\curvearrowright$ & $\curvearrowright$ & 으 & $ㅇ$ & in & - & $\curvearrowright$ & $=$ & 으 & 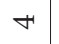 & $\neg$ & $a$ & - & $\infty$ & 0 & in & 6 & H & - & $\wedge$ \\
\hline$\sim$ & in & $\sim$ & $\stackrel{n}{\sim}$ & 10 & $\Xi$ & $\stackrel{n}{\sim}$ & 6 & 0 & 0 & 6 & $\infty$ & $\wedge$ & $\stackrel{\sim}{\sim}$ & $\simeq$ & $\cong$ & $\gamma$ & 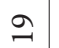 & 으 & + & 0 & $m$ \\
\hline-1 & -1 & $N$ & $m$ & 0 & 0 & 0 & 0 & 0 & 0 & 0 & 0 & 0 & 0 & 0 & 0 & - & 0 & 0 & $\neg$ & $\sim$ & - \\
\hline تु & 느 & $\hat{m}$ & 占 & $\curvearrowright$ & $\vec{\infty}$ & $\infty$ & in & है & $\infty$ & ஜำ & $\stackrel{\sim}{\sim}$ & r & $\stackrel{\infty}{\sim}$ & $\mathcal{F}$ & $\stackrel{m}{n}$ & ț & $\stackrel{\infty}{m}$ & $N$ & $F$ & $\stackrel{m}{f}$ & ก \\
\hline 능 & $\stackrel{\circ}{\circ}$ & 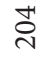 & $\stackrel{\circ}{\stackrel{1}{N}}$ & $\stackrel{m}{+}$ & ले & $\stackrel{\partial}{ }$ & $\ddot{\sim}$ & $\stackrel{m}{=}$ & $\Xi$ & $\stackrel{m}{n}$ & $\stackrel{20}{2}$ & $\leftrightarrows$ & $\stackrel{N}{N}$ & $\stackrel{\infty}{-}$ & $\stackrel{\infty}{-}$ & F & $\tilde{\sigma}$ & নे & $\infty$ & $\stackrel{\infty}{\sigma}$ & in \\
\hline 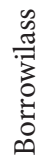 & 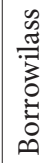 & 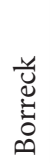 & 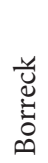 & 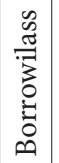 & $\begin{array}{l}\text { ũ } \\
\stackrel{\Xi}{0} \\
\infty \\
\infty\end{array}$ & $\begin{array}{l}\tilde{u} \\
\stackrel{u}{0} \\
0 \\
\infty\end{array}$ & 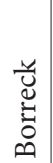 & 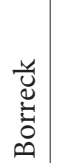 & 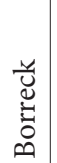 & 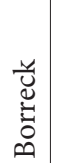 & $\begin{array}{l}\text { ü } \\
\stackrel{u}{u} \\
0 \\
\infty\end{array}$ & 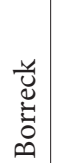 & 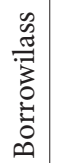 & $\begin{array}{c}u \\
\tilde{u} \\
\stackrel{0}{0} \\
0\end{array}$ & $\begin{array}{l}\text { ũ } \\
\stackrel{u}{0} \\
0 \\
\infty\end{array}$ & 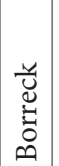 & 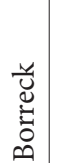 & 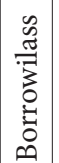 & $\begin{array}{l}0 \\
\frac{0}{0} \\
\frac{0}{3} \\
0 \\
0 \\
0 \\
\infty \\
\infty\end{array}$ & 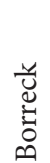 & 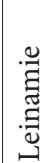 \\
\hline 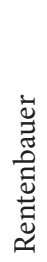 & 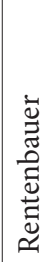 & 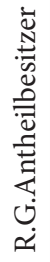 & 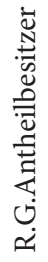 & 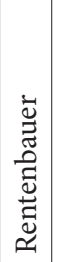 & 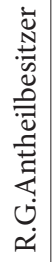 & 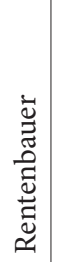 & 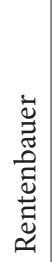 & 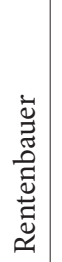 & 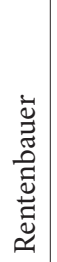 & 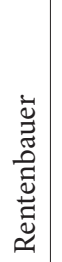 & 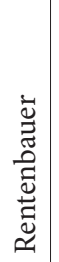 & 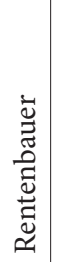 & 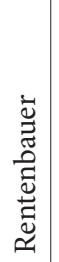 & 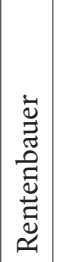 & 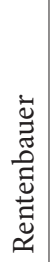 & 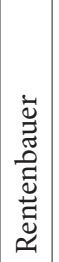 & 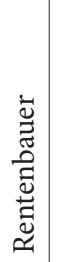 & 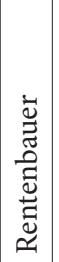 & 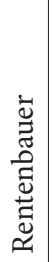 & 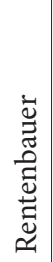 & 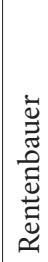 \\
\hline 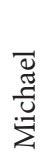 & 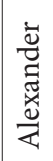 & 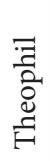 & 烒 & $\stackrel{\Xi}{\Xi}$ & 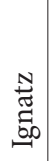 & 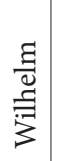 & 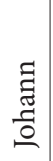 & 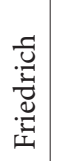 & $\overline{\vec{z}}$ & 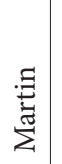 & 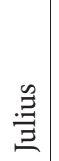 & $\stackrel{0}{\Xi}$ & 雚 & 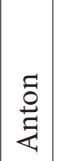 & 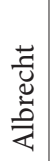 & 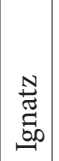 & 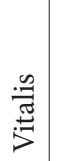 & N & 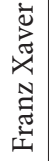 & 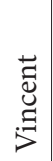 & $\bar{\Xi}$ \\
\hline 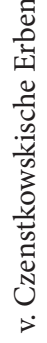 & 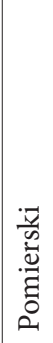 & 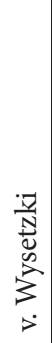 & 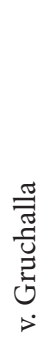 & 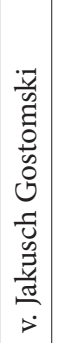 & 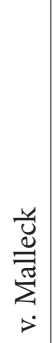 & 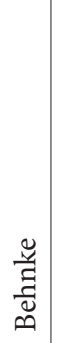 & $\begin{array}{l}\tau \\
\overline{0} \\
0 \\
\text { 至 }\end{array}$ & 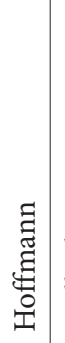 & 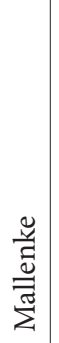 & 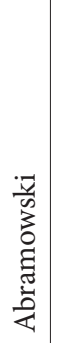 & 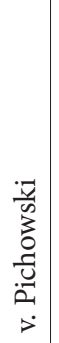 & 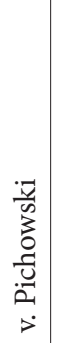 & 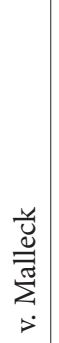 & $\mid \begin{array}{c}\vec{y} \\
\bar{n} \\
z \\
0 \\
0 \\
\tilde{z} \\
0 \\
0 \\
0 \\
\dot{c}\end{array}$ & $\begin{array}{l}\overrightarrow{7} \\
0 \\
0 \\
0 \\
0 \\
0 \\
0 \\
\dot{0}\end{array}$ & 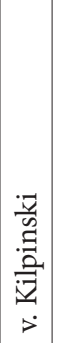 & 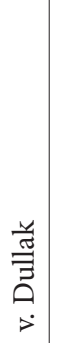 & 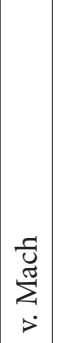 & 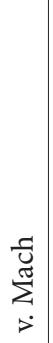 & 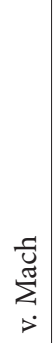 & $\begin{array}{l}3 \\
0 \\
0 \\
0 \\
0 \\
0 \\
0 \\
0\end{array}$ \\
\hline$\stackrel{\stackrel{n}{N}}{\stackrel{n}{*}}$ & 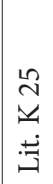 & 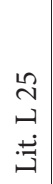 & 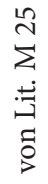 & 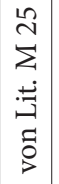 & 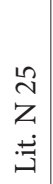 & $\begin{array}{l} \pm \\
\stackrel{\Xi}{Z} \\
z\end{array}$ & $\begin{array}{l}n \\
0 \\
\vdots \\
z\end{array}$ & $\begin{array}{l}0 \\
0 \\
z \\
z\end{array}$ & $\begin{array}{l}\beth \\
\stackrel{0}{z}\end{array}$ & $\begin{array}{l}\infty \\
\stackrel{\infty}{1} \\
\dot{z}\end{array}$ & $\begin{array}{l}\stackrel{a}{2} \\
\stackrel{0}{z}\end{array}$ & $\begin{array}{l}\stackrel{1}{1} \\
\text { o } \\
z\end{array}$ & $\begin{array}{l}\text { N } \\
0 \\
z\end{array}$ & 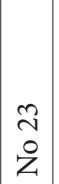 & $\begin{array}{l}\stackrel{H}{N} \\
\stackrel{0}{Z} \\
Z\end{array}$ & $\begin{array}{l}\stackrel{2}{N} \\
0 \\
z \\
z\end{array}$ & $\begin{array}{l}\stackrel{2}{N} \\
o \\
z\end{array}$ & $\begin{array}{l}\hat{\imath} \\
\hat{z} \\
z\end{array}$ & $\begin{array}{l}\stackrel{\infty}{\sim} \\
\stackrel{2}{z} \\
z\end{array}$ & $\begin{array}{l}2 \\
\grave{z} \\
\dot{z}\end{array}$ & $\begin{array}{l}0 \\
\text { n } \\
\stackrel{2}{z} \\
\text { z }\end{array}$ \\
\hline$\dot{a}$ & $\dot{\ddots}$ & $\dot{\exists}$ & $\stackrel{\sim}{\sim}$ & $\ddot{\sim}$ & $\dot{\amalg}$ & in & $\ddot{\theta}$ & 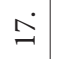 & $\stackrel{\infty}{-}$ & $\stackrel{\sigma}{-}$ & $\dot{\sim}$ & $\vec{\sim}$ & ป & $\ddot{\sim}$ & $\stackrel{+}{\sim}$ & $\stackrel{\circ}{2}$ & $\dot{\sim}$ & 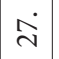 & $\stackrel{\infty}{\sim}$ & ৯ & $\dot{m}$ \\
\hline
\end{tabular}



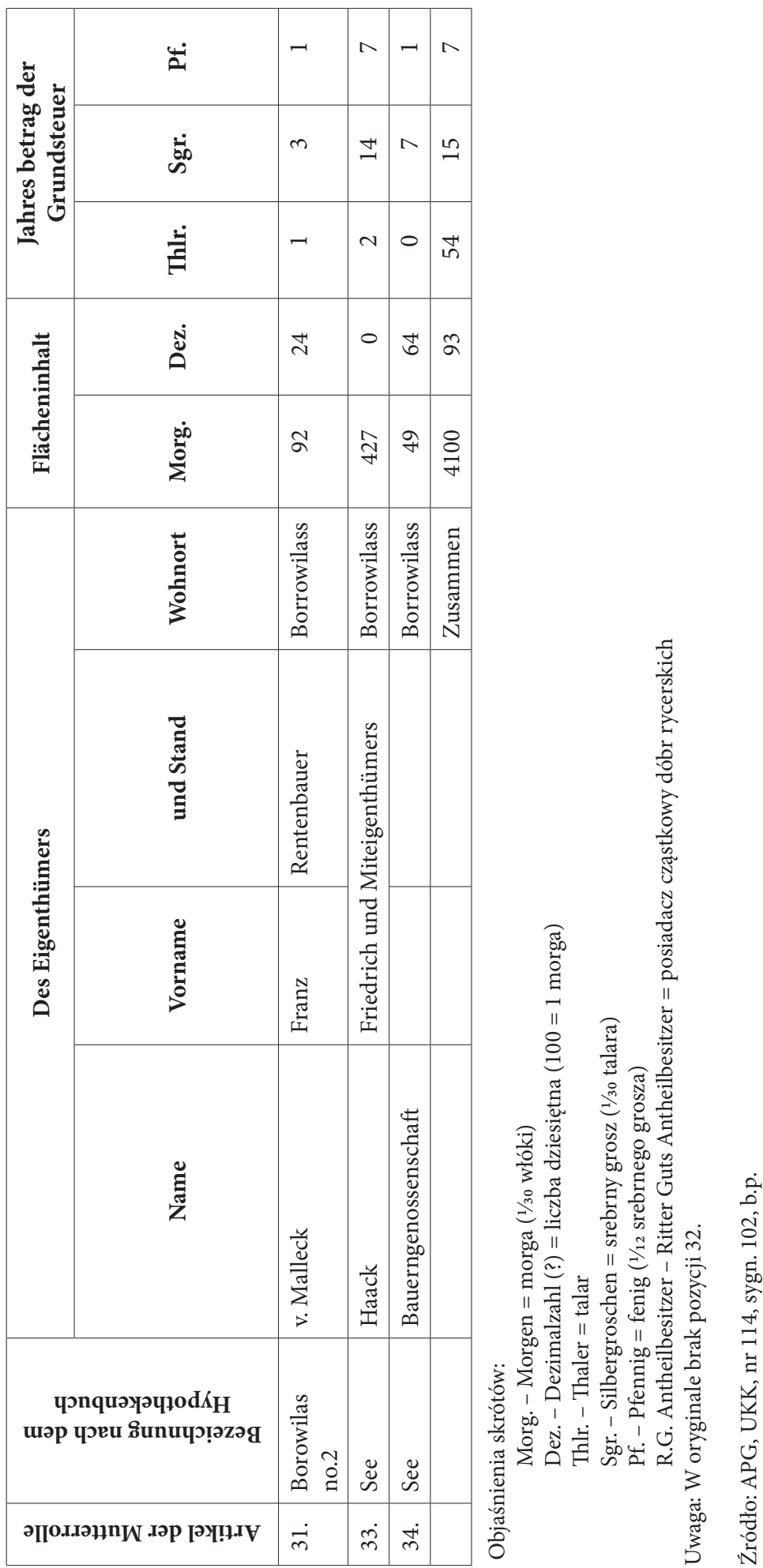


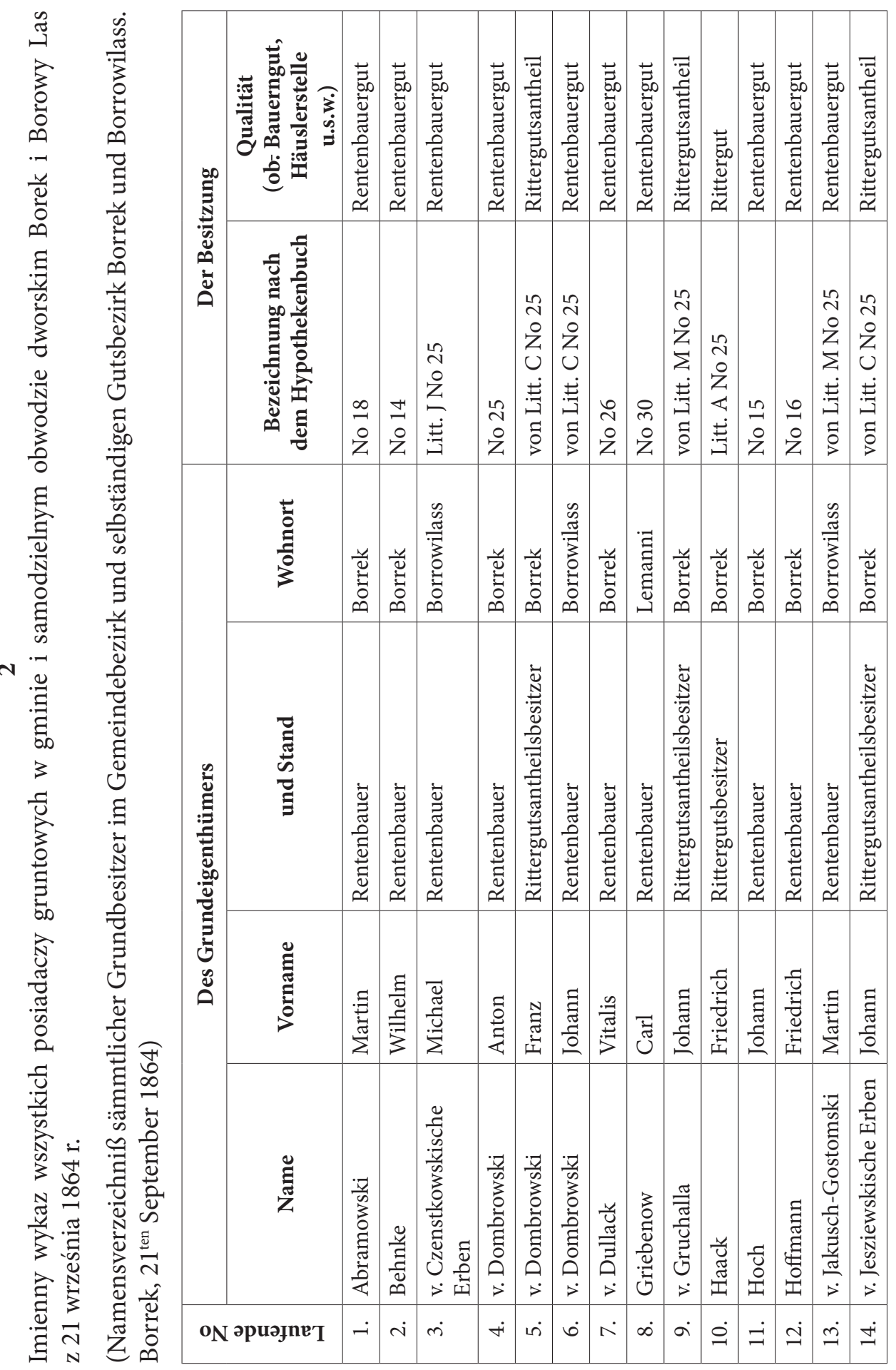




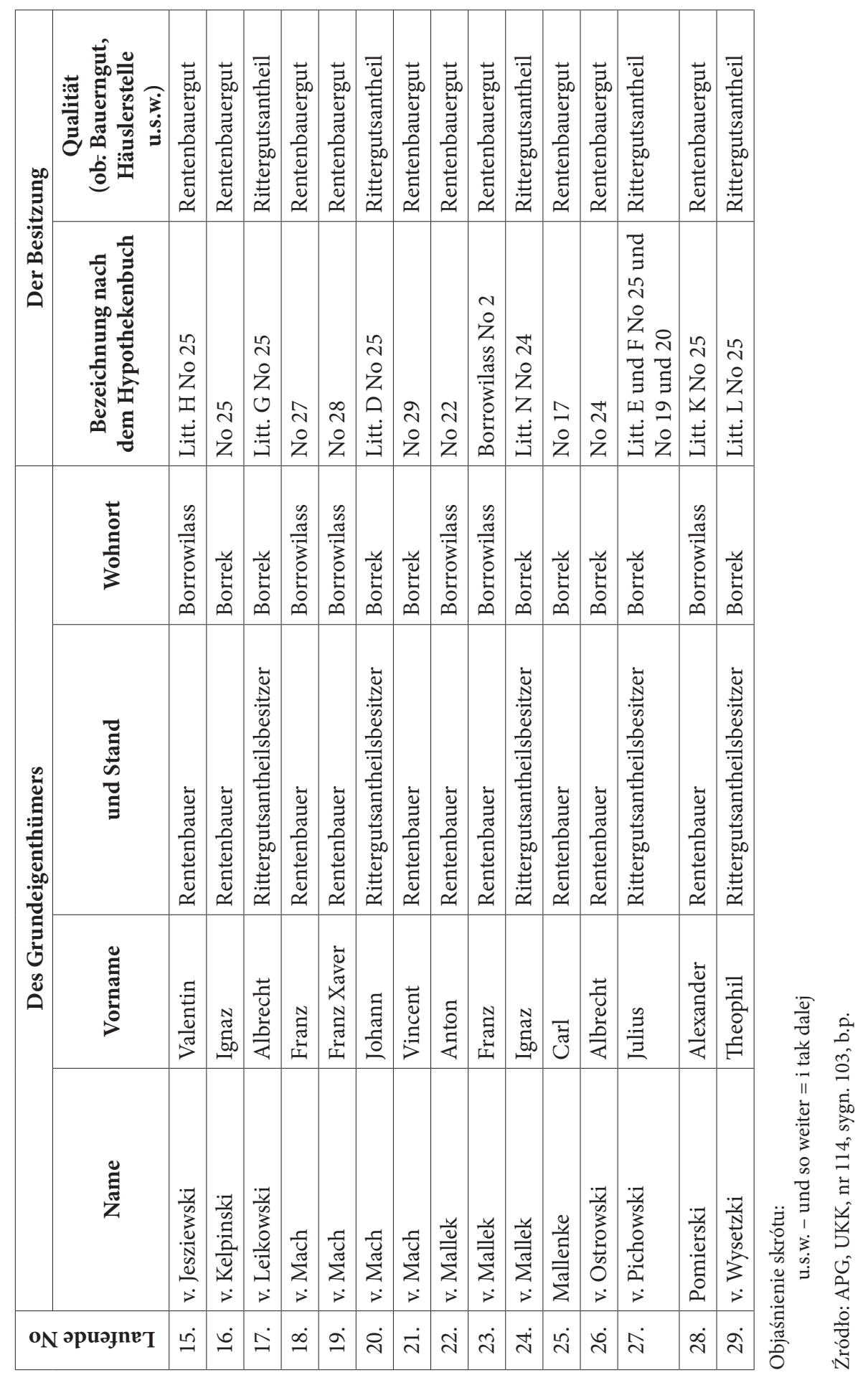




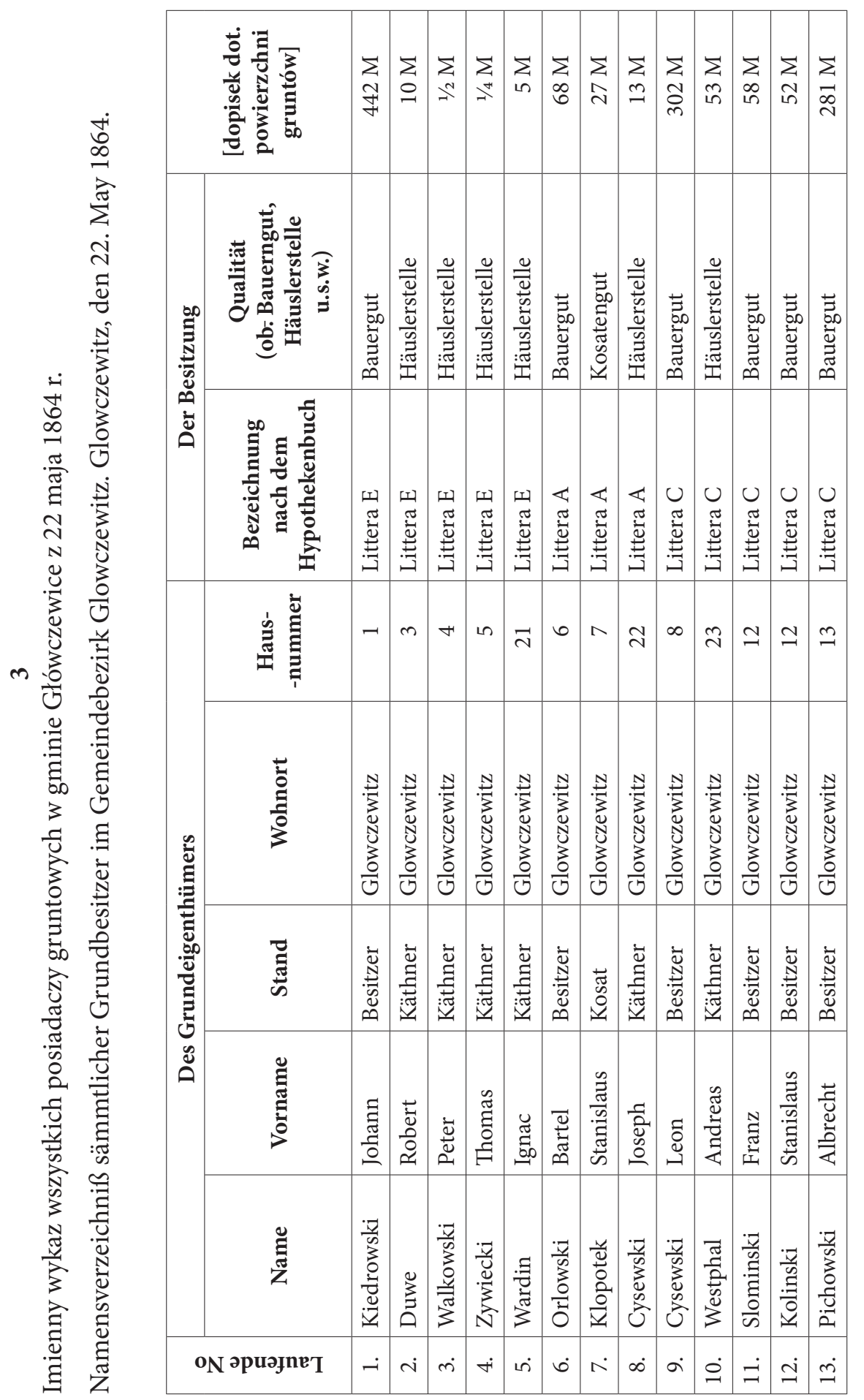




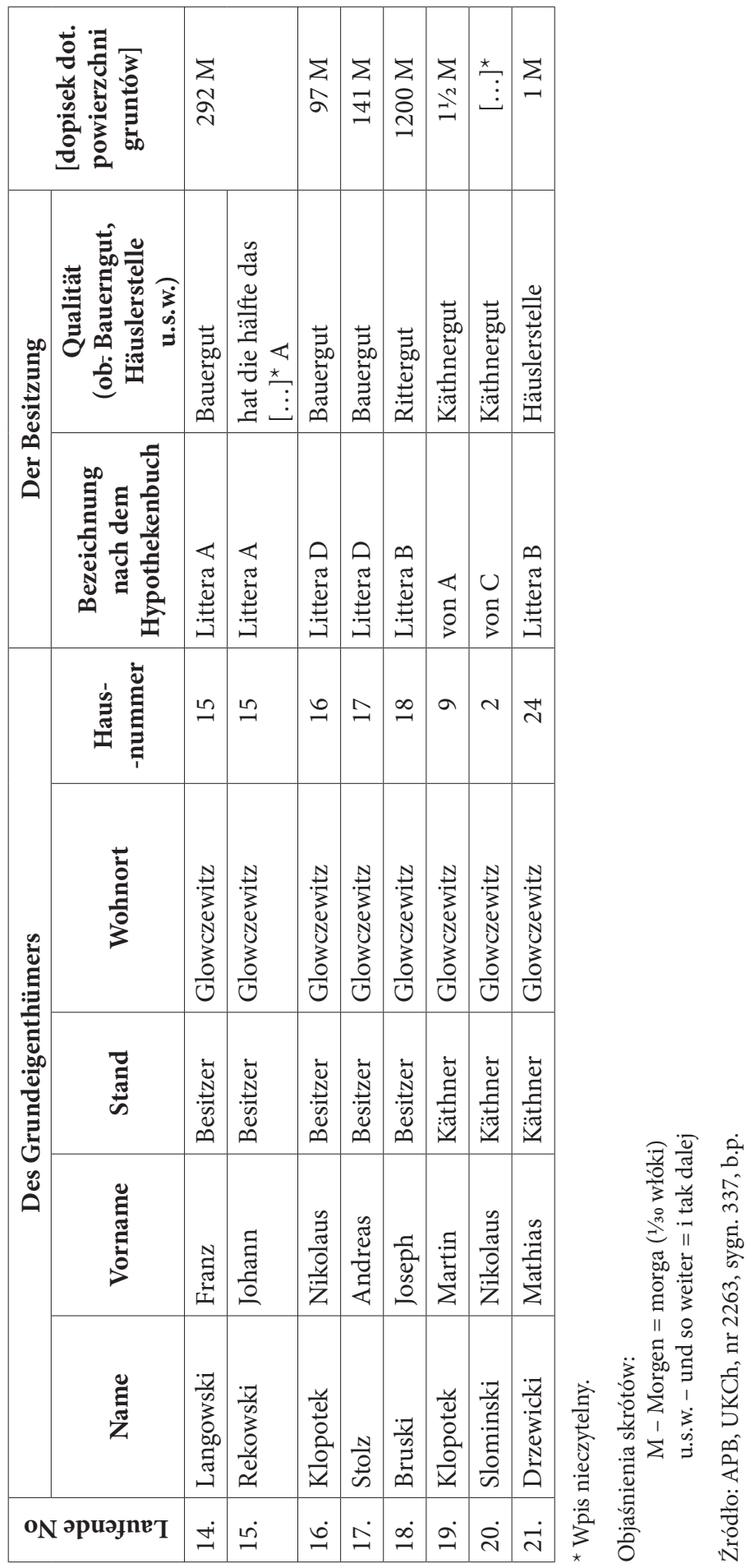




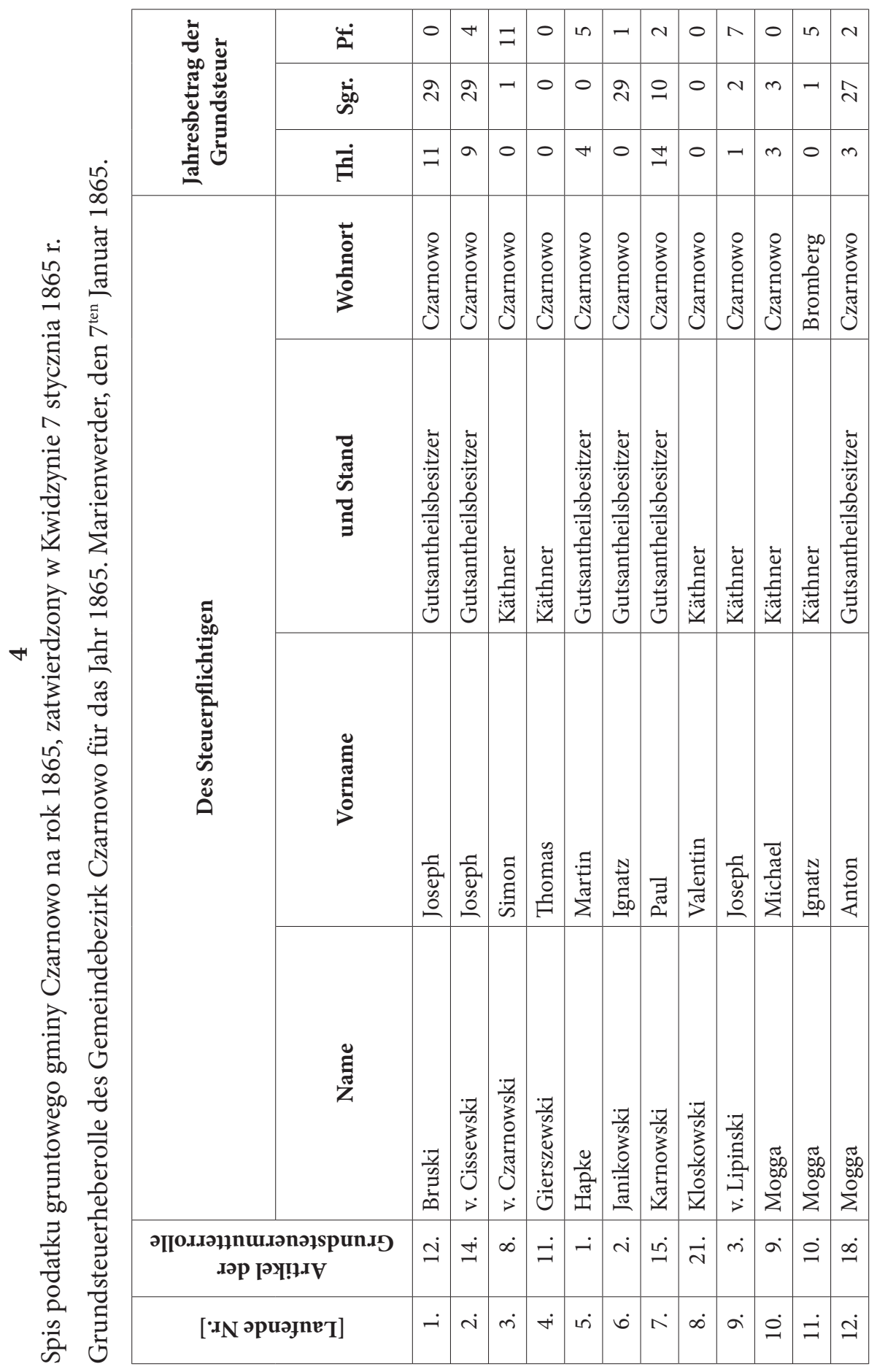




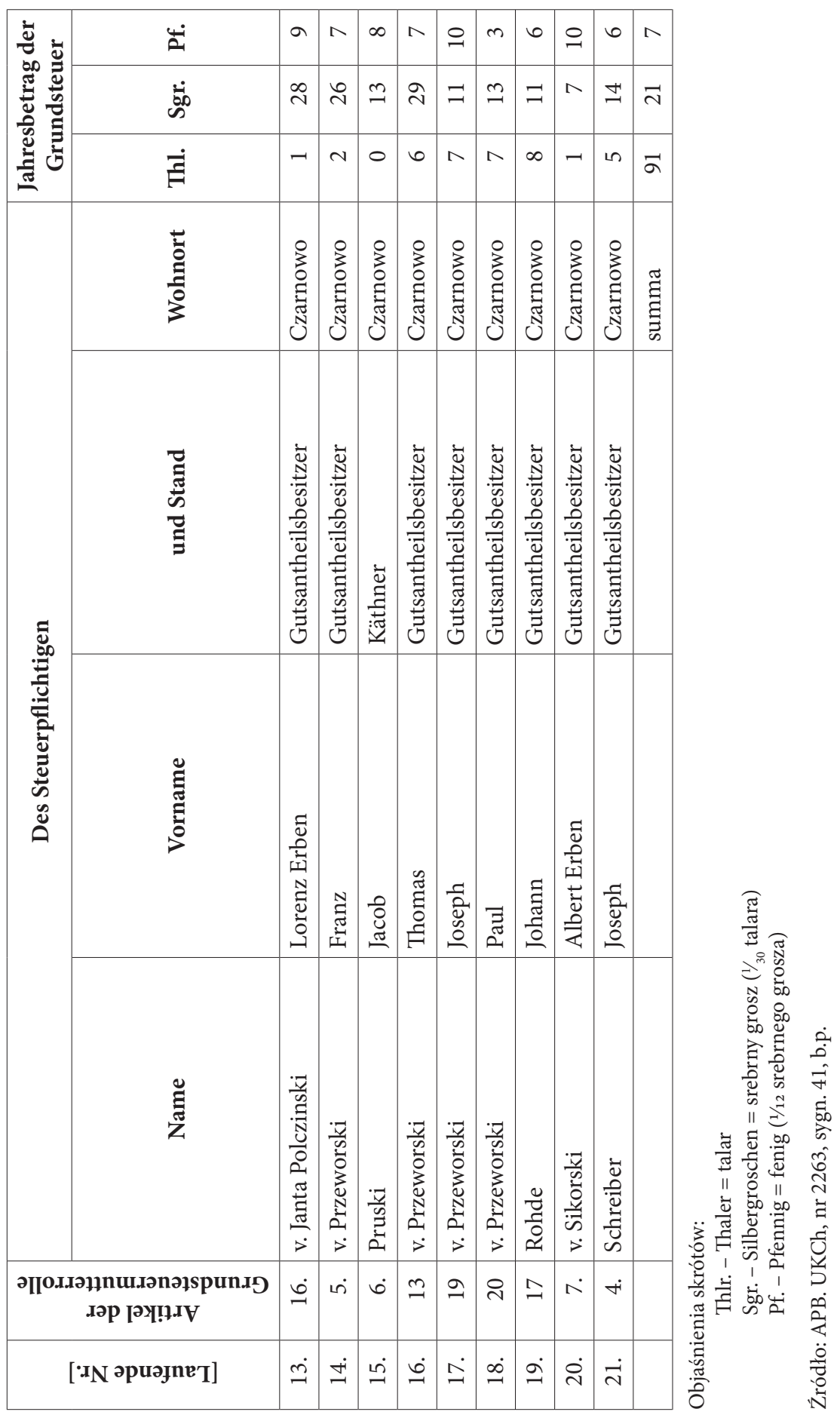




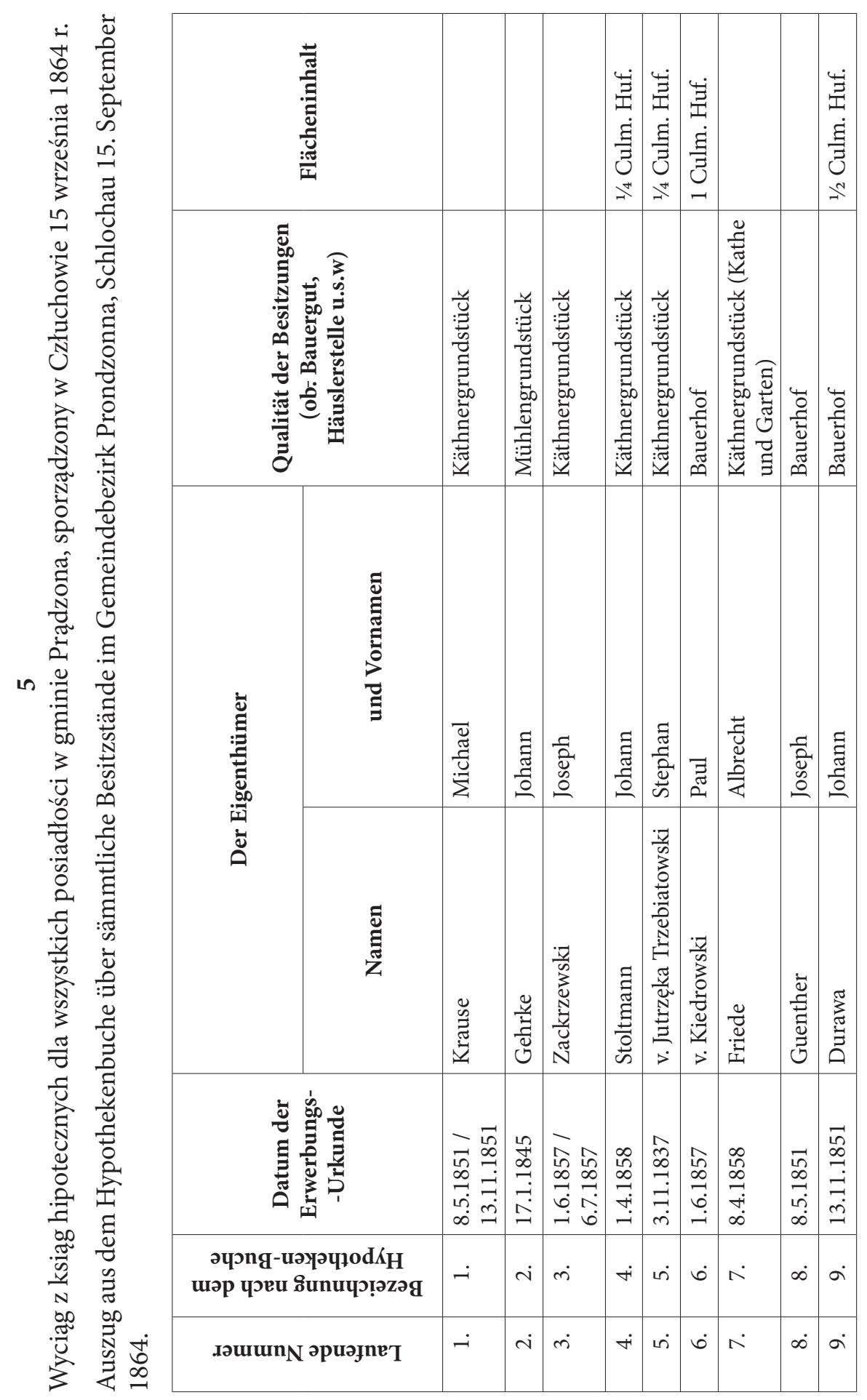




\begin{tabular}{|c|c|c|c|c|c|c|c|c|c|c|c|c|}
\hline & 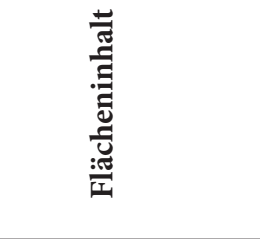 & & $\begin{array}{l}\text { 금 } \\
\text { ì }\end{array}$ & & 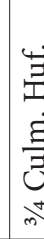 & & & & & & & \\
\hline & 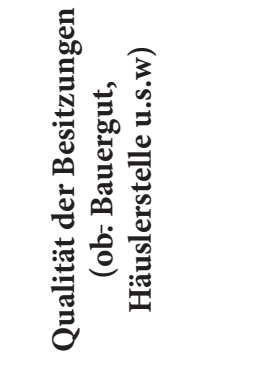 & 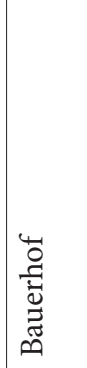 & 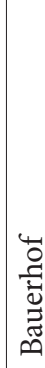 & & 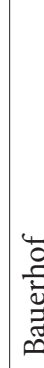 & 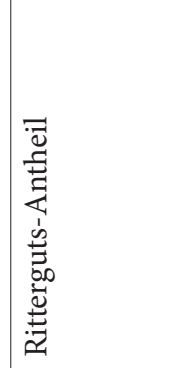 & 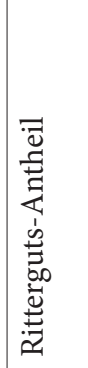 & 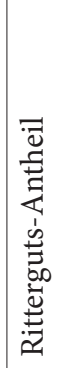 & 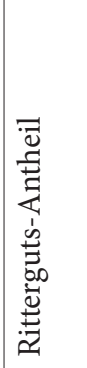 & 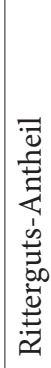 & 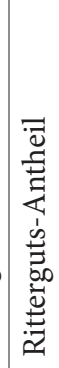 & 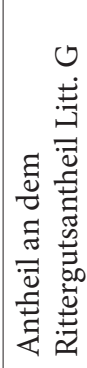 \\
\hline 峁 & 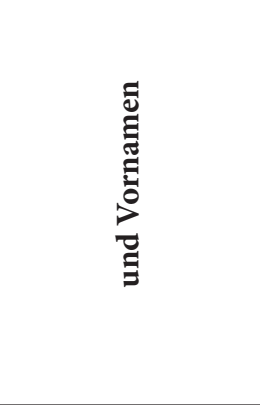 & $\underset{\mathscr{Z}}{\breve{G}}$ & $\begin{array}{l}\text { בี } \\
\text { בे } \\
\text { के }\end{array}$ & & 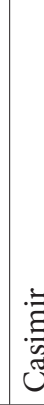 & 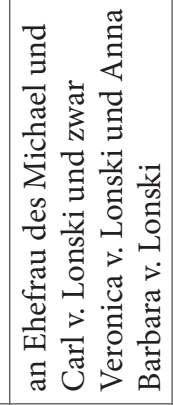 & 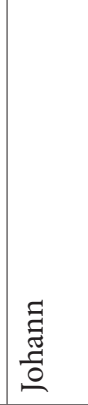 & $\vec{z}$ & 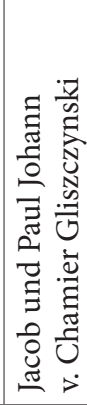 & 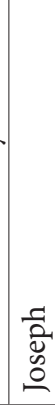 & 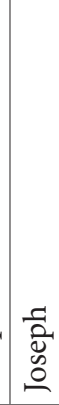 & 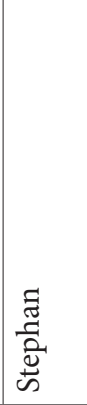 \\
\hline 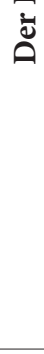 & 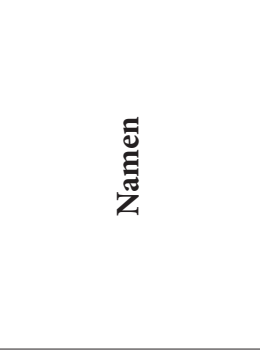 & 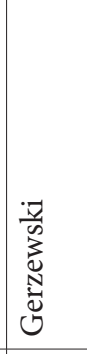 & 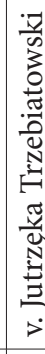 & & 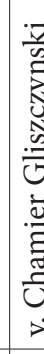 & $\begin{array}{l}\frac{i}{7} \\
0 \\
0 \\
0 \\
0 \\
0 \\
0\end{array}$ & $\begin{array}{l}7 \\
\frac{7}{0} \\
3 \\
0 \\
0 \\
0 \\
0\end{array}$ & 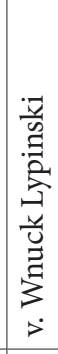 & 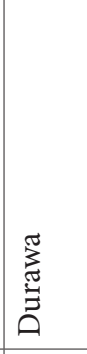 & 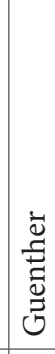 & 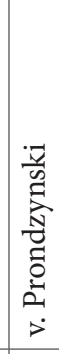 & 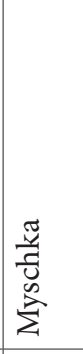 \\
\hline & 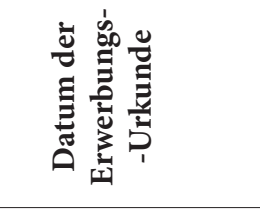 & 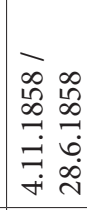 & 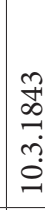 & 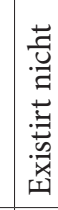 & 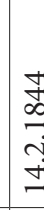 & 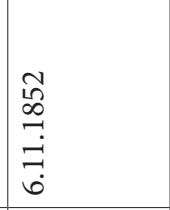 & 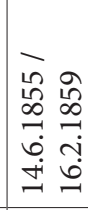 & 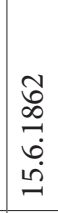 & 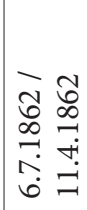 & 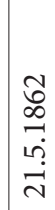 & 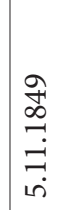 & $\begin{array}{l}0 \\
0 \\
\infty \\
-1 \\
i \\
6 \\
-1\end{array}$ \\
\hline & 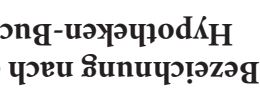 & $\dot{9}$ & $\exists$ & $\stackrel{2}{2}$ & $\stackrel{9}{2}$ & $\ddot{I}$ & $\stackrel{\operatorname{n}}{-}$ & 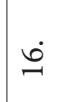 & 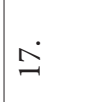 & $\stackrel{\infty}{\rightarrow}$ & 2 & $\dot{i}$ \\
\hline & uun $_{N}$ әрuәуnет & $\stackrel{0}{1}$ & $\exists$ & & 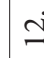 & $\ddot{\sim}$ & $\ddot{I}$ & in & $\ddot{-}$ & 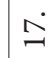 & $\stackrel{\infty}{\infty}$ & $\stackrel{9}{2}$ \\
\hline
\end{tabular}




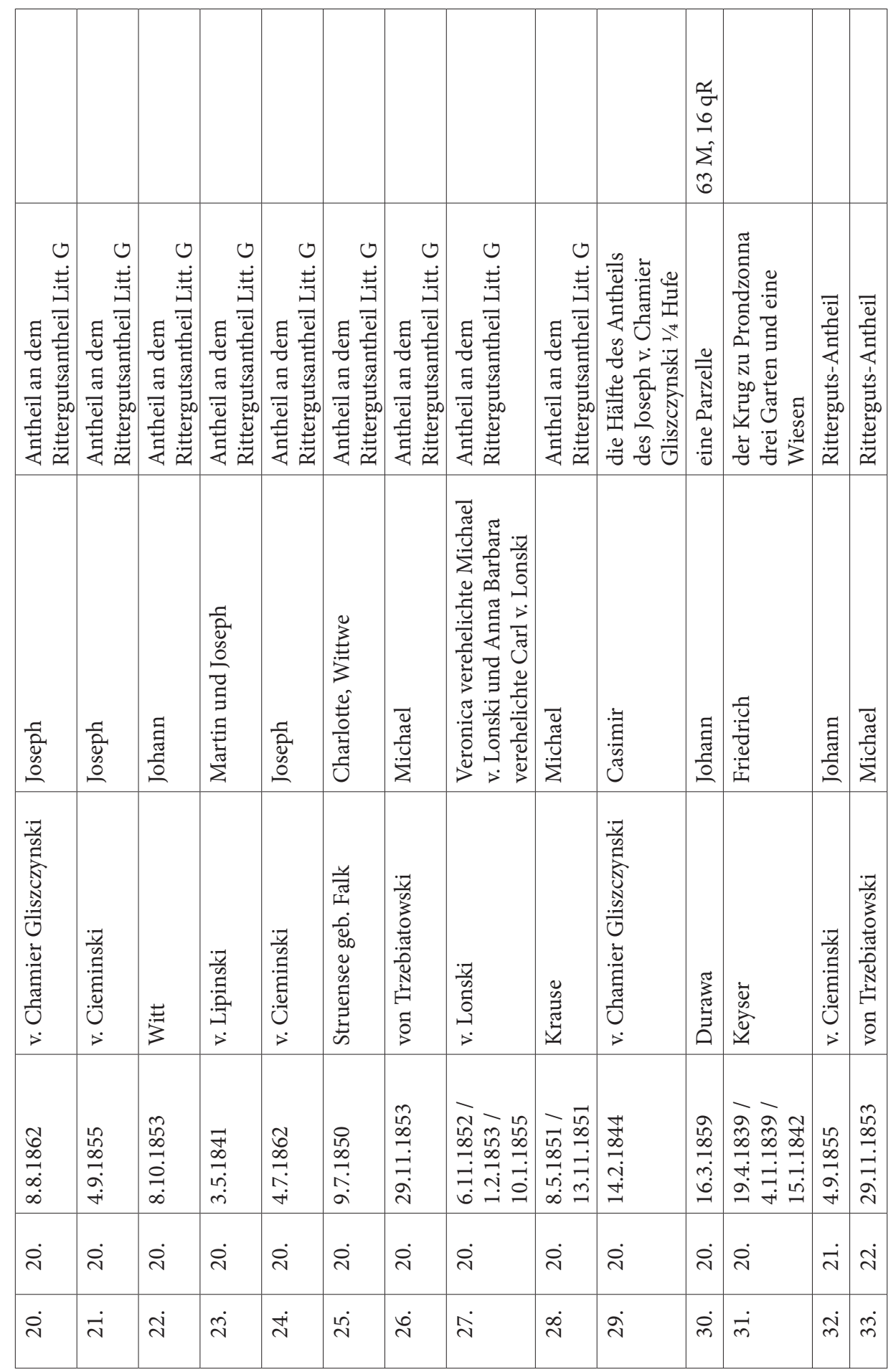




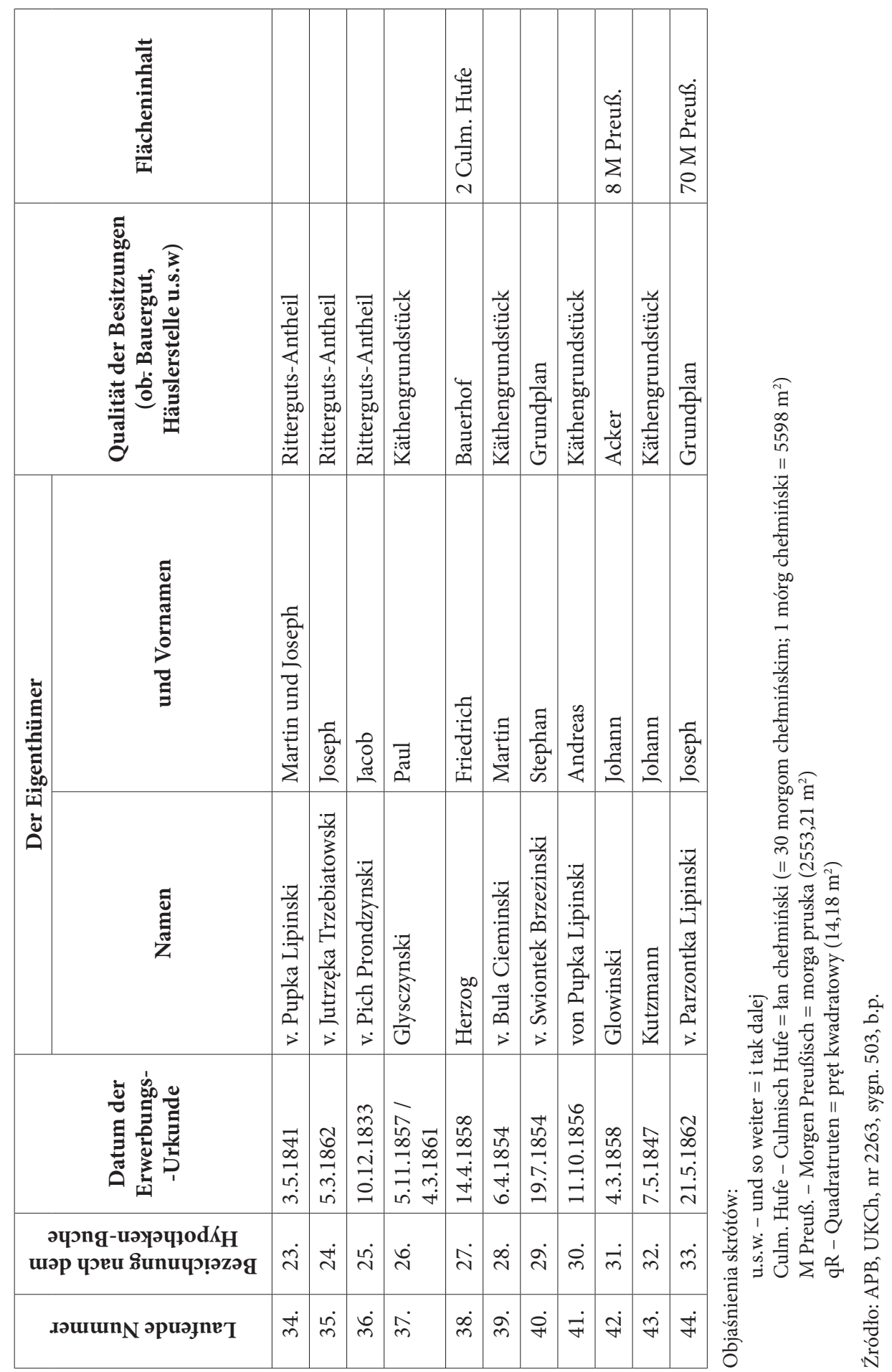




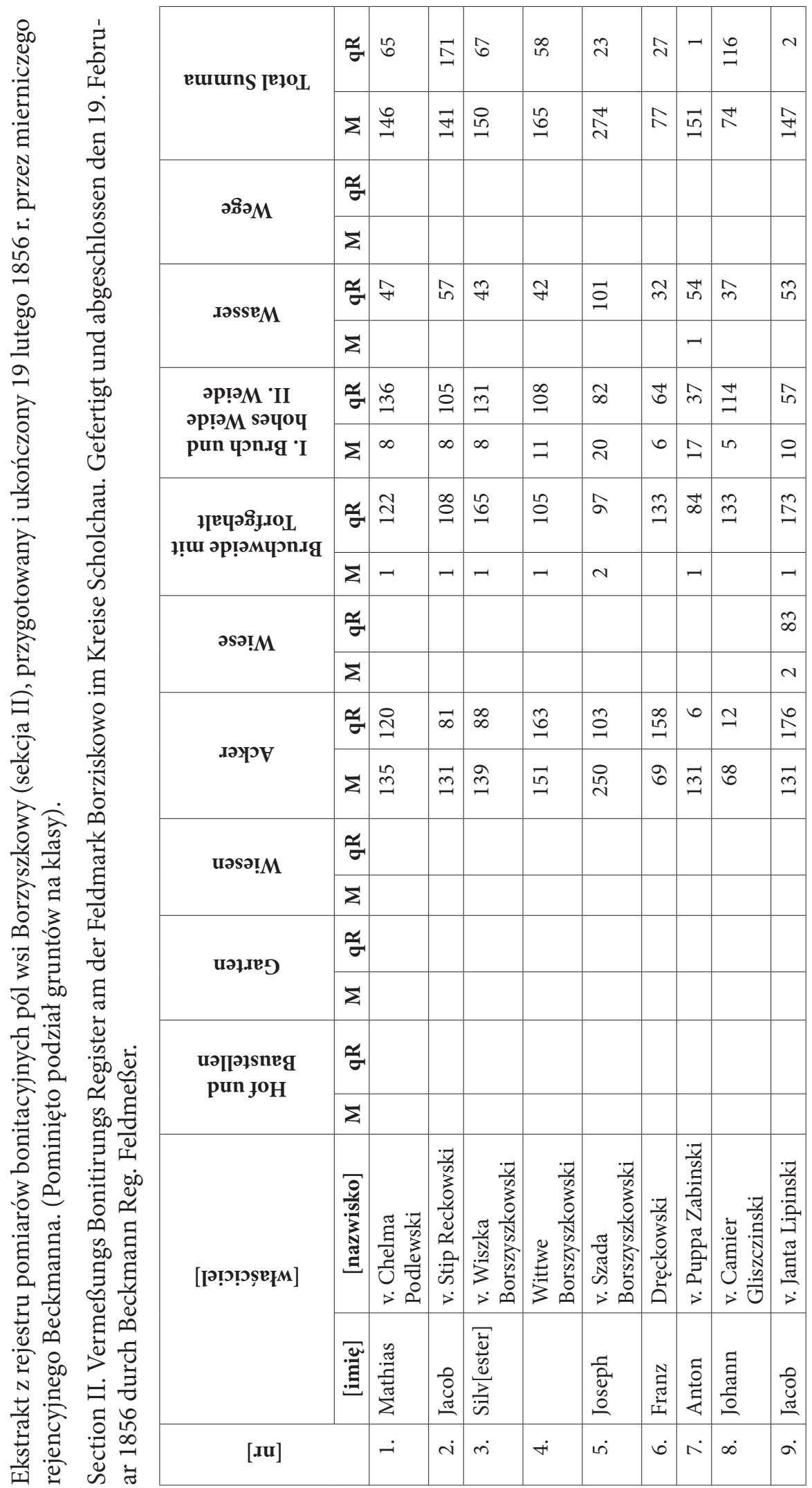




\begin{tabular}{|c|c|c|c|c|c|c|c|c|c|c|c|c|c|c|c|}
\hline \multirow{2}{*}{ euuuns [']०్L } & $\underline{x}$ & 아 & $\stackrel{R}{I}$ & $\vec{\beth}$ & m & in & $\vec{\sim}$ & a & กี & 字 & I & $\stackrel{20}{=}$ & $\vec{b}$ & 듬 & $\approx$ \\
\hline & $\Sigma$ & $\stackrel{g}{g}$ & $\stackrel{\infty}{=}$ & $\begin{array}{l}\infty \\
10 \\
1\end{array}$ & 烎 & Ln & ले & $\infty$ & $\stackrel{\infty}{\sim}$ & $\stackrel{0}{=}$ & ㄴ & 9 & $\stackrel{\sim}{\sim}$ & n & 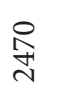 \\
\hline \multirow{2}{*}{ วठิวM } & 뜸 & & & & & & & & & & & & $\vec{b}$ & $\underline{\triangle}$ & กิ \\
\hline & $\sum$ & & & & & & & & & & & & ᄂ & $\wedge$ & m \\
\hline \multirow{2}{*}{ Iəsse $M$} & 뜸 & $\stackrel{2}{\sim}$ & & in & $\vec{m}$ & & จิ & హ゙ & $m$ & 2 & ๖ & $\stackrel{10}{=}$ & & & $\stackrel{n}{m}$ \\
\hline & $\Sigma$ & & & & & & & & & & - & 9 & & & ֻ \\
\hline \multirow{2}{*}{$\begin{array}{c}\text { әр!әM 'II } \\
\text { әр!әM sәчоч } \\
\text { pun чวn.Ig 'I }\end{array}$} & 뜸 & gิ & $\stackrel{\infty}{\stackrel{\infty}{\beth}}$ & ปे & 음 & $\stackrel{\infty}{\stackrel{\circ}{\prime}}$ & 븜 & $\infty$ & Fे & 点 & 우 & & & & $\stackrel{\infty}{=}$ \\
\hline & $\Sigma$ & $\infty$ & $\cong$ & $a$ & $\infty$ & $m$ & $m$ & 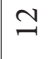 & in & $n$ & $\stackrel{2}{\sim}$ & & & & $\stackrel{+}{\sigma}$ \\
\hline \multirow{2}{*}{ 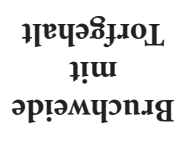 } & 米 & in & 욱 & $\stackrel{m}{\sim}$ & $\stackrel{10}{\sharp}$ & & & 음 & & $\infty$ & & & & & $\stackrel{0}{\simeq}$ \\
\hline & $\Sigma$ & - & - & $\neg$ & $\neg$ & & & & & - & & & & & ส \\
\hline \multirow{2}{*}{ วsə!M } & 뜸 & 6 & & & & & & & 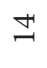 & & & & & & $\underline{\underline{\theta}}$ \\
\hline & $\Sigma$ & & & & & & & & $H$ & & & & & & 6 \\
\hline \multirow{2}{*}{ IכYगV } & 뜨 & 6 & ป & $\infty$ & $\stackrel{ }{\beth}$ & भ & $\vec{\sim}$ & $\stackrel{\infty}{\wedge}$ & $\stackrel{\infty}{n}$ & $\stackrel{0}{=}$ & & & & & $\infty$ \\
\hline & $\Sigma$ & $\stackrel{\vec{m}}{ }$ & $\stackrel{\infty}{0}$ & 烎 & $\stackrel{0}{n}$ & กิ & $\stackrel{n}{m}$ & $\stackrel{0}{1}$ & $\stackrel{g}{\exists}$ & 8 & & & & & $\begin{array}{l}\stackrel{0}{\infty} \\
\stackrel{\sim}{\sim}\end{array}$ \\
\hline \multirow[t]{2}{*}{ นəรə! M } & 뜸 & & & & & & & & & & & & & & \\
\hline & $\Sigma$ & & & & & & & & & & & & & & \\
\hline \multirow[t]{2}{*}{ 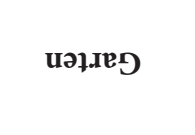 } & 땀 & & & & & & & & & & & & & & \\
\hline & $\Sigma$ & & & & & & & & & & & & & & \\
\hline \multirow{2}{*}{ 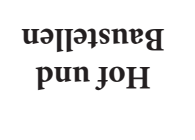 } & $\approx$ & & & & & & & & & & & & & & \\
\hline & $\Sigma$ & & & & & & & & & & & & & & \\
\hline \multirow[t]{2}{*}{ 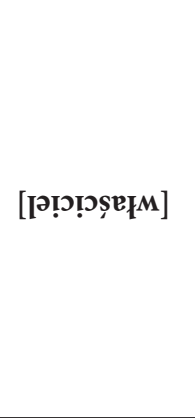 } & 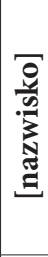 & 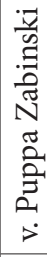 & 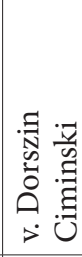 & 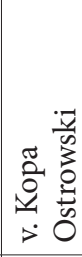 & 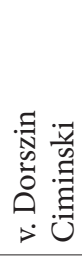 & 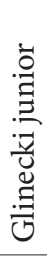 & 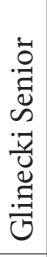 & $\begin{array}{l}\frac{\pi}{4} \\
\tilde{0} \\
\text { Е }\end{array}$ & 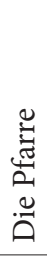 & 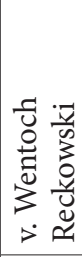 & 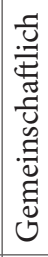 & $\begin{array}{l}\ddot{\Xi} \\
\infty \\
\vdots \\
\tilde{U}\end{array}$ & 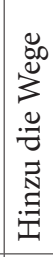 & 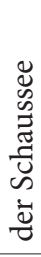 & 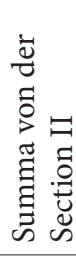 \\
\hline & 氙 & 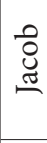 & 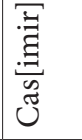 & 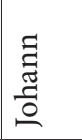 & 苂 & 苂 & 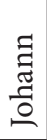 & 志 & & 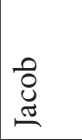 & & & & & \\
\hline \multicolumn{2}{|l|}{$[\mathbf{I u}]$} & $\stackrel{0}{\circ}$ & $\Xi$ & $\stackrel{\sim}{\sim}$ & $\ddot{\sim}$ & $\dot{ \pm}$ & $\stackrel{1}{=}$ & $\stackrel{0}{\circ}$ & $\stackrel{\check{L}}{ }$ & $\stackrel{\infty}{-}$ & $\stackrel{-}{\circ}$ & & & & \\
\hline
\end{tabular}




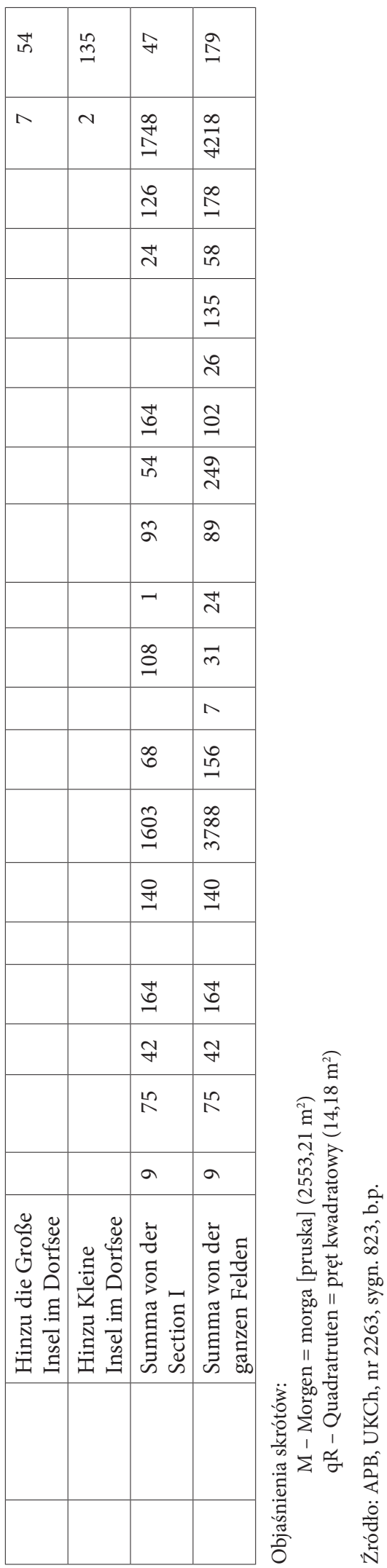




\section{Tomasz Rembalski \\ Land Tax Records of Prussian Cadastral Offices as Source Material for the Study of Socio-economic Structure of Kashubian Petty Nobility in West Prussia}

(1861-1872)

\section{Summary}

Nineteenth-century tax sources for the Polish territories annexed by Prussia, which are preserved in a relatively large number, have not so far met with significant interest from researchers, apart from a few exceptions from Wielkopolska. The aim of this work is to highlight the usefulness for specific research (socio-economic structure of Kashubian petty nobility) of the records regarding land tax, created by the cadastral offices in three districts of West Prussia Province (Westpreußen), namely: Chłuchów (Schlochau), Chojnice (Konitz) and Kartuzy (Karthaus). Such approach is motivated by good recognition of these documents.

Cadastral offices under Prussian rule have been brought to life by the Act of 21 May 1861 on a different regulation of property tax (Gesetz vom 21. Mai 1861 betreffend die anderweite Regelung der Grundsteuer). In accordance with $₫ 1$ of the Act, land tax was separated from building tax. The provisions of the Act, in accordance with $\$ 11$, entered into force only from 1 January 1865, because by that time the newly established offices had to be properly prepared, by collecting documentation, cadastral measurements and assessment, which was to become the basis for the cadastral administration. The task of cadastral offices was to make groundwater measurements and calculate an average actual income from them (Reinertrag) to estimate the land and building tax.

Analysis of the acts of cadastral authorities, despite significant shortcomings in the archives, confirms their great research value. They contain information on the type and size of land, tax height (unfortunately preserved to a small extent), and finally the social status of their respective owners, which makes it possible to get interesting data on the socio-ownership structure in petty nobility villages of Kaszuby in West Prussia Province. 